\title{
Bilateral Macroeconomic Connectivity and Crisis Patterns
}

Jong-Hee Kim

Chonbuk National University, Jeonju, Republic of Korea

\begin{abstract}
This paper estimates the degree of connectivity between the 27 countries of the European Union. Within it the 17 countries of the Eurozone are believed to have stronger sectorlevel connectivity than other countries. We focus on the connection between those relationships and crisis indicators. The main findings are: (i) Economic fluctuations, fiscal deficit conditions, and degree of economic interaction were all found to have a powerful effect on connectivity between Eurozone nations, especially in the areas of trade and banking. (ii) The Currency Crisis Indicator for countries that have adopted the euro was also observed to increase continuously after Eurozone membership. (iii) Economic coordination was observed to have a more negative effect on currency crisis risk for Eurozone countries than relative fiscal vulnerability. However, fiscal vulnerability accounted for a larger portion of the impact of trade connectivity on crisis is stronger than did cyclical coordination.
\end{abstract}

JEL Classifications: E60, F10, F40

Keywords: Currency Crisis Indicator, Connectivity, Vulnerability

\footnotetext{
* Corresponding Author: Jong-Hee Kim; Chonbuk National University, Economics College of Commerce, 567 Baekjedaero, Jeonju-si, Jeollabuk-do, 561-756, Republic of Korea; Tel: +82 632703007, Fax: +82 632703040, E-mail: jonghk5@, jbnu.ac.kr.
}

Acknowledgements: This paper was supported by research funds of Chonbuk National University in 2015. 


\section{Introduction}

The possibility of a long-term recession in the global economy has become the subject of growing concern as many major nations, including the countries of the Eurozone and the United States, have wrestled with protracted economic difficulties since the eruption of the global financial crisis of 2008. When nations are closely interconnected both domestically and internationally, a financial or monetary crisis in one country or region can have an impact on the global economic situation. Countries with lesser economic strength and poorer fiscal conditions are typically both quicker to succumb to these negative effects and are slower to recover.

If one country is weaker than others in terms of economic variables such as its real sector (production, consumption, investment, hiring), financial sector (currency flows, interest rates, stock values), and/or the external sector (exchange rates, imports, exports), this may leave it especially prone to uncertainties and more exposed to financial or monetary crisis in the event of an external shock, while making much slower recovery, a fact that is especially true when the degree of economic interdependency between countries is as high as it is today.

For this reason, many countries are now attempting to minimize the potential losses and maximize the benefits from increased exchange by forming economic communities, in which barriers to transactions are lowered to promote gains for the countries within them (Jaumotte and Sodsriwiboon 2010, Barattieri 2011). These countries may succeed in finding ways to blunt the effects of macroeconomic shocks by forming sector-level linkages within the community to respond to the potential uncertainties of the future.

However, the effects of connectivity are not always positive. Historical examples and research show an increasing level of connectivity in recent years between the macroeconomic sectors of different countries, particularly in terms of elements, associated with the external economy. Some findings provide grounds for skepticism as to whether these linkages necessarily enable countries to reap substantial gains. As realworld examples, the European Union (EU), which constitutes the most highly integrated bloc of nations anywhere in the world, and the countries of the Eurozone in particular are facing situations of deepening imbalance. More worrisome still is the possibility of structural macroeconomic shocks, as contagion has been demonstrated to be more likely to spread between countries at a faster rate when they are closely interconnected.

These facts inevitably give rise to apprehensions that connectivity between countries 
may actually be increasing the likelihood of encountering crises. If existing examples or research indicates that structural shocks from economic recession or crisis travel more quickly between strongly interconnected countries, especially at a time when such linkages are becoming more and more common, then it is also necessary to determine whether this connectivity increases the chances of a crisis actually occurring.

Most other studies have focused on the extent to which connectivity increases contagion, with some more recent ones focusing on the relative vulnerability between countries as a factor behind this increase. That is the area upon which this paper turns its focus: the question of whether increased connectivity raises the chances of a crisis occurring, and the factors at play in this effect. The 27 countries of the EU offer excellent subjects for such an analysis. This economic community was formed to provide greater gains to its members through exchange and to eliminate variables of economic uncertainty. Moreover, there is a separate economic community among those 27 countries that has more fully realized the basic goals of an economic bloc, namely the 17 countries that have adopted the euro as a common currency. In addition to their shared currency, they also maintain uniform interest rates effectively, which arguably give them a closer degree of connectivity than any other countries or communities. Moreover, they have recently been experiencing conditions of economic crisis, which have compounded the aftereffects of the global economic crisis of 2008 2009, prompting some skeptics to question the sustainability of the enterprise.

This study examines the degree of connectivity between the macroeconomic sectors of trade, industry, and banking for the 27 member states of the EU, as well as the 17 countries that use the euro as a common currency and the 10 that do not. In particular, it looks at the reasons for their increasing connectivity and examines whether these ties actually increase the possibility of an economic crisis or other structural shock. Its focus differs from previous research in that it estimates the degree to which relative connectivity influences the possibility of crisis, rather than the degree of crisis contagion or the role of vulnerability.

\section{Literature Review}

In a situation where countries are engaging in exchange as actively as they do today, 
the openness of a country has a large influence on its trade balance. That is to say, the increase in foreign exchange between countries brings about an improvement in the conditions for trade through an increased demand for domestic goods and increases the profits of corporations, which can further bring about increased investment. The higher the degree of openness, the more we see effects such as these (Corsetti and Müller 2006, Müller 2008).

In principle, increased connectivity as a result of greater openness may function to maximize gains by lowering entry barriers to transactions, while at the same time blunting the effects of economic uncertainties that result from structural shocks or similar phenomena. However, actual examples and research findings indicate that links between the macroeconomic sectors of different countries, especially those within particular communities, may actually exacerbate imbalances between them.

Countries experience increasing connectivity as a result of active trade (Eichengreen, Rose, and Wyplosz 1997, Glick and Rose 1999). Occasionally, the trade imbalance that results from trading inside an economic union can even be higher than trading with countries outside of the region. Such cases have become common in the Eurozone in recent years, specifically among countries in southern Europe (Barnes, Lawson, and Radziwill 2010, Berger and Nitsch 2012). The cause for this lies in the fact that the economic gap between the states that make up the Eurozone economic union was too great at the time it was founded, and the fact that this gap has widened during the 10 years since the Eurozone was launched.

Recent years have seen an abundance of research findings showing that crisis conditions spread more quickly when structural shocks occur in the countries of an economic community characterized by relatively close ties. Fratzscher (2000) found that crisis contagion increases in cases of closer trade and financial market links, while Karmann, Greßmann, and Hott (2002) discovered a greater contagion effect from increased connectivity in the case of monetary crisis conditions. In particular, some findings indicate that crisis contagion is observed to be stronger within groups characterized by higher levels of connectivity between countries (e.g., the EU or Eurozone) than in other communities. Demyanyk, Ostergaard, and Sorensen (2008) observed a greater degree of risk exposure and risk contagion among the EU nations than among the states of the US. Kim, Park, and Sung (2012) estimated crisis contagion for the Eurozone countries and the 50 states of the US, finding a greater effect in the more closely interconnected former group than in the latter group.

Because of these findings, a broad range of studies have been undertaken to determine 
why the countries in such economic communities should experience greater contagion effects despite the closeness of their ties. Weakness in the sectors of a country's economy may be one of the root causes for crisis conditions. As trade openness has led to greater connectivity between nations, the relative vulnerability of certain states vis-à-vis their trading partners has been recognized as an important factor in their interdependence (Kaminsky and Reinhart 1999). According to De Gregorio and Valdez (2001), these connections between countries actually weaken in the event of a structural change such as an economic crisis or boom, so that the relative weakness of one country may be a crucial variable in the eruption of a crisis. In other words, while connectivity between countries is important in the spreading of contagion associated with an economic crisis or similar event, relative vulnerability should also be taken into account in the transmission of that contagion (Edwards 1999). Relative weakness in terms of such macroeconomic sectors as the real economy, the financial economy, and the external economy may leave a country more susceptible to a financial or foreign exchange crisis in the event of an external shock, while reducing the speed of its subsequent recovery.

This relative weakness ultimately functions to deepen imbalances between countries. While these vulnerabilities and their exacerbation may result from any number of variables, research indicates that economic strength, fiscal conditions, and changes in labor variables and real economic indicators are the principal causes.

In particular, a country's economic growth rate is often mentioned as a factor to explain imbalances as a result of relative vulnerability between countries. Large relative gaps in Gross Domestic Product (GDP) growth rates as well as GDP volatility and GDP forecasts are important in determining the way in which a trade imbalance occurs and the extent of that imbalance between the countries engaging in trade (Brzozowski and Prusty 2011, Lane and Pels 2012). The financial situation of a government has a significant meaning as well. Budget extension policies that worsen a government's budget balance also weaken the current account balance, and additional government measures that are taken to respond to this can cause the trade imbalance with other trading partner countries to deteriorate (Truman 2004). In particular, if a country's budget deficit continues, that country's saving rate will continue to decrease, and this can become a cause for a continuing deficit in trade with other countries (Chinna and Ito 2005). Another possibility has to do with fluctuations with respect to the labor sector, such as declining productivity or rising labor costs (Bussiere et al. 2005, Kotsios 2012). Such cases are associated with a high probability of imbalances arising in trade with other countries. In addition to this, real economic indexes such as the exchange rate, the 
interest rate, and the rate of inflation have also been fingered as major causes for the occurrence of trade imbalances (Estrella and Mishikin 1998, Nickel and Vansteenkiste 2008, Bulut 2009, Craighed and Hineline 2011). This is to say that drastic fluctuation in such indices in comparison with a trading partner can lead to a trade imbalance. In particular, even when drastic fluctuation of economic indices such as these occurs in a trading partner, the country at issue can be influenced in this way (Fracasso and Sciavo 2009).

The variables mentioned here function to undermine a country's competitive edge, give rise to imbalances between countries, and amplify the ripple effect when a crisis does occur. One question that arises, then, is whether stronger connectivity of macroeconomic sectors between two or more countries actually increases the potential for a crisis to erupt. In other words, do such linkages expose larger weaknesses in conditions of structural change such as sudden economic upheavals or crisis conditions?

Much research exists to show that weaknesses in a country's macroeconomic sectors are associated with more negative performance on a number of crisis indicators (Van den End 2006, Baldacci, McHugh, and Petrova 2011). However, few studies have examined the effects that connectivity between countries has on these indicators. De Gregorio and Valdes (2001) did isolate linkages in different countries' macroeconomic indicators by sector, but their focus was more on the results of these linkages, and the relationship between them and crisis contagion effects.

This paper estimates the degree of connectivity between the 27 countries of the EU, which already has a longstanding history as a tightly bound economic community, and within it the 17 countries of the Eurozone, which are believed to have stronger sectorlevel connectivity than other countries. Taking into account the fact that these countries use the same currency and the same interest rates, it examines the effects that these linkages have had on the Currency Crisis Index (CCI) for the countries within these two communities. In particular, it focuses on the aforementioned variables that influence connectivity between countries, determining their impact on the CCI, and the channels through which it travels, as structural changes in the economy and government finances interact with trade, industry, and banking connectivity between nations. It is hoped that these results will lend credence to findings on the relationship between economic ties and crisis indicators. 


\section{Data}

This study looks at the relationships between the 27 countries of the EU in terms of their trade, industry, and banking connectivity, with a particular focus on the connection between those relationships and crisis indicators. It also isolates two subsets of this community, i.e., the 17 countries that have adopted the euro and the 10 that have not, in order to examine the differences in their findings. Because the 17 countries in the Eurozone all joined at different times, the study also compares findings before and after their membership.

This paper uses time series data from 1990 to 2011, and in order to express the calculation of the effect of these variables in greater detail, it has assembled quarterly rather than annual data. This adds up to a total of 88 quarters of data for each country from the first quarter of 1990 to the fourth quarter of 2011.

\section{Table 1. Composition of 27 sample countries}

\begin{tabular}{|c|l|}
\hline \multirow{2}{*}{ EU 27 countries } & $\begin{array}{l}\text { Austria, Belgium, Bulgaria, Cyprus, Czech Republic, } \\
\text { Denmark, Estonia, Finland, France, Greece, Germany, } \\
\text { Hungary, Ireland, Italy, Latvia, Lithuania, Luxembourg, } \\
\text { Malta, Netherlands, Poland, Portugal, Romania, } \\
\text { Slovak Republic, Slovenia, Spain, Sweden, U.K. }\end{array}$ \\
\hline \multirow{5}{*}{ Euro 17 countries } & $\begin{array}{l}\text { Austria(1999:1), Belgium(1999:1), Cyprus(2008:1), } \\
\text { Estonia(2011:1), Finland(1999:1), France(1999:1), } \\
\text { Greece(2001:1), Germany(1999:1), Ireland(1999:1), } \\
\text { Italy(1999:1), Luxembourg(1999:1), Malta(2008:1), } \\
\text { Netherlands(1999:1), Portugal(1999:1), } \\
\text { Slovak Republic(2009:1), Slovenia(2007:1), Spain(1999:1) }\end{array}$ \\
\hline \multirow{2}{*}{ Non-euro 10 countries } & $\begin{array}{l}\text { Bulgaria, Czech Republic, Denmark, Hungary, Latvia, } \\
\text { Lithuania, Poland, Romania, Sweden, U.K. }\end{array}$ \\
\hline
\end{tabular}

(Note) The timing of joining the euro is given in parentheses.

The variables that are used to evaluate the degree of connectivity between countries are the percentage of imports and exports out of GDP (transactions by group), the percentage of gross value added by individual industries, and the Chinn-Ito Index. 
Government revenues, expenditures, and debt relative to GDP are used as indicators of fiscal vulnerability, while interest rates, exchange rates, and foreign reserves as a percentage of GDP are used to calculate monetary crisis indicators. GDP per capita growth rate is used to estimate the relative levels of economic power between countries.

All of the data is seasonally adjusted, and the sources it drew upon are the World Bank's World Development Indicators \& Global Development Finance, the Organization for Economic Co-operation and Development (OECD)'s OECD.StatExtracts, the European Commission's Eurostat, the International Monetary Fund (IMF)'s e-Library Data, and Chinn-Ito's financial openness index (http://web.pdx.edu/ ito/Chinn-Ito_ website.htm) for estimating banking connectivity.

The Chinn-Ito index is an index measuring a country's degree of capital account openness. The index was initially introduced by Chinn and Ito (Journal of Development Economics 2006). The Chinn-Ito index is based on the binary dummy variables that codify the tabulation of restrictions on cross-border financial transactions reported in the IMF's Annual Report on Exchange Arrangements and Exchange Restrictions. It also contains capital account openness index series for the time period of 1970 2013 for 182 countries.

Table 2 below explains the raw data that is used to populate the variables as explained above. 
Table 2. Preliminary data of euro area countries

\begin{tabular}{|c|c|c|c|c|c|c|c|c|c|}
\hline & \multicolumn{3}{|c|}{ EU 27 countries } & \multicolumn{3}{|c|}{ Non-euro 10 countries } & \multicolumn{3}{|c|}{ Euro 17 countries } \\
\hline & Obs. & Ave. & Std. & Obs. & Ave. & Std. & Obs. & Ave. & Std. \\
\hline $\begin{array}{c}\Delta y \\
\text { per capita }\end{array}$ & 2,069 & 1.32 & 7.43 & 737 & 2.48 & 11.03 & 1,332 & 0.69 & 4.18 \\
\hline $\begin{array}{c}\text { Export } \\
\text { (GDP ratio) }\end{array}$ & 2,196 & 8.55 & 8.48 & 772 & 3.92 & 4.58 & 1,424 & 5.15 & 5.98 \\
\hline $\begin{array}{c}\text { Import } \\
\text { (GDP ratio) }\end{array}$ & 2,196 & 11.27 & 14.51 & 772 & 4.39 & 5.20 & 1,424 & 7.43 & 11.97 \\
\hline $\begin{array}{l}\text { Agriculture et al. } \\
\text { (GVA ratio) }\end{array}$ & 1,944 & 3.45 & 2.56 & 712 & 4.58 & 3.55 & 1,232 & 2.81 & 1.38 \\
\hline $\begin{array}{l}\text { Construction } \\
\text { (GVA ratio) }\end{array}$ & 1,944 & 6.24 & 1.55 & 712 & 5.98 & 1.52 & 1,232 & 6.40 & 1.55 \\
\hline $\begin{array}{l}\text { Manufacturing } \\
\text { (GVA ratio) }\end{array}$ & 1,944 & 18.61 & 5.12 & 712 & 19.30 & 4.66 & 1,232 & 18.21 & 5.33 \\
\hline $\begin{array}{l}\text { Wholesale et al. } \\
\text { (GVA ratio) }\end{array}$ & 1,944 & 23.62 & 4.03 & 712 & 24.17 & 4.20 & 1,232 & 23.30 & 3.89 \\
\hline $\begin{array}{c}\text { Fin. Intermediation } \\
\text { (GVA ratio) }\end{array}$ & 1,944 & 23.22 & 6.34 & 712 & 20.43 & 4.87 & 1,232 & 24.84 & 6.53 \\
\hline $\begin{array}{c}\text { Public, Community } \\
\text { (GVA ratio) }\end{array}$ & 1,944 & 21.39 & 3.59 & 712 & 20.94 & 4.38 & 1,232 & 21.65 & 3.01 \\
\hline $\begin{array}{l}\text { Financial Openness } \\
\text { Index }\end{array}$ & 2,216 & 1.61 & 1.33 & 792 & 1.31 & 1.54 & 1,424 & 1.77 & 1.18 \\
\hline $\begin{array}{c}\text { Revenue } \\
\text { (GDP ratio) }\end{array}$ & 1,612 & 37.12 & 14.49 & 584 & 36.99 & 16.47 & 1,028 & 37.20 & 13.25 \\
\hline $\begin{array}{l}\text { Expenditure } \\
\text { (GDP ratio) }\end{array}$ & 1,580 & 39.72 & 14.48 & 584 & 39.09 & 15.76 & 996 & 40.09 & 13.66 \\
\hline $\begin{array}{l}\text { Government Debt } \\
\text { (GDP ratio) }\end{array}$ & 1,817 & 50.34 & $\begin{array}{l}29.27 \\
\end{array}$ & 661 & 37.55 & 19.83 & 1,156 & 57.65 & 31.22 \\
\hline$\Delta r$ & 2,161 & -1.44 & 14.96 & 751 & -1.43 & 18.15 & 1,410 & -1.44 & 12.96 \\
\hline$\Delta e r$ & 2,227 & 0.35 & 3.77 & 764 & 0.65 & 4.96 & 1,463 & 0.20 & 2.95 \\
\hline $\begin{array}{c}\text { Reserve } \\
\text { (GDP ratio) }\end{array}$ & 2,167 & 17.67 & 31.73 & 758 & 29.28 & 35.53 & 1,409 & 11.42 & 27.55 \\
\hline
\end{tabular}

(Notes) (i) Quarterly average value for 1990:1 2011:4.

(ii) Obs. stands for number of observations, Ave. stands for average, Std. stands for standard deviation. 
While the 27 countries of the EU have had an average annual per capita economic growth rate of $1.32 \%$, and the 10 non-euro nations have maintained a level of $2.48 \%$, the 17 countries that use the euro have shown a much lower rate of $0.69 \%$. Also, the countries of the EU have experienced trade deficit conditions, with exports and imports representing $8.55 \%$ and $11.27 \%$ of GDP within the region, respectively. The non-euro countries have also experience a trade deficit, but a relatively small one, with exports and imports respectively representing $3.92 \%$ and $4.39 \%$ of GDP. The deficit has been much larger for the Eurozone, where exports and imports respectively represent $5.15 \%$ and $7.43 \%$ of GDP.

For EU nations, the ratios of gross value added of 6 classification industries per total industry are 3.45\% (agriculture, fishing), 6.24\% (construction), 18.61\% (manufacturing), $23.62 \%$ (wholesale and retail trade, hotels and restaurants, transport), 23.22\% (financial intermediation, real estate), 21.39\% (public administration and community services, activities of households). Here, the ratio of wholesale and retail trade, hotels and restaurants; transport is the highest in non-euro countries, while the ratio of financial intermediation, real estate is the highest in Eurozone countries.

In terms of Chinn-Ito's Financial Openness Index, a measure of financial connectivity, the EU countries had an overall average of 1.61, with Eurozone countries earning a higher rating (1.77) than countries that do not use the euro (1.54).

In terms of government fiscal conditions, the countries of the EU are running a deficit, with fiscal revenues accounting for $37.12 \%$ of GDP to expenditures of $39.72 \%$. These percentages were $36.99 \%$ and $39.09 \%$, respectively, for non-euro nations, and higher on both scores for countries using the euro, $37.20 \%$ and $40.09 \%$, respectively. As a result, the government balance of trade relative to GDP had a higher absolute value for the Eurozone $(-2.89 \%)$ than for the non-euro countries $(-2.10 \%)$. Government debt averaged $50.34 \%$ of GDP for the EU countries as whole; the $37.55 \%$ rate for non-euro countries was relatively low compared to the $57.65 \%$ rate for the Eurozone, which was higher than the average for the EU.

Finally, no major differences were observed between the countries that did and did not use the euro in terms of increases in interest rates. This measure, used to calculate monetary crisis indicators for a particular country, averaged $-1.44 \%$ per year for the EU as a whole. Exchange rate variability averaged $0.35 \%$ per year for all EU countries, with a higher level $(0.65 \%)$ for non-euro countries. Countries that used the euro had a rate of $0.20 \%$, which was lower than the average for all EU nations. This suggests that the usage of a common currency has blunted the effects of currency rate fluctuations. Foreign 
reserves averaged $17.67 \%$ of GDP for the EU and $29.28 \%$ for non-euro countries. The Eurozone rate was substantially lower at $11.42 \%$.

These basic data show that the 17 countries of the Eurozone have larger trade and fiscal deficits than the 10 non-euro countries and a relatively smaller percentage of foreign reserves relative to GDP. Government debt is relatively large, while GDP per capita is growing at a rate roughly one-third that of non-euro countries.

\section{Model and Empirical Results}

\section{A. Estimation of bilateral connectivities}

To estimate the effects of trade, industry, and banking connectivity between countries on the possibility of a crisis occurring, it is first necessary to determine the extent of this connectivity. For this paper, the following equations are used to calculate bilateral connectivities in each of these areas:

bilateral Trade Connectivity: $T S_{i, t}=\frac{1}{N} \sum_{j=1}^{n}\left(\frac{x_{i j, t}+m_{i j, t}+x_{j i, t}+m_{j i, t}}{2 Y_{i, t}+2 Y_{j, t}}\right)$

bilateral Industry Connectivity: $I S_{i, t}=\frac{1}{N} \sum_{j=1}^{n}\left(1-\sum_{n=1}^{N}\left|I D_{i n, t}-I D_{j n, t}\right|\right)$

bilateral Bank Connectivity: $B S_{i, t}=\frac{1}{N} \sum_{j=1}^{n}\left(\frac{1}{2}\left(C I_{i, t}-C I_{j, t}\right)\right)$

Equation (1) estimates the connectivity between two countries in terms of trade, with $T S_{i, t}$ representing the trade connectivity of country $i$ at time $t . x_{i j, t}$ indicates the total amount exported by country $i$ to country $j$, while $m_{i j, t}$ shows the total amount imported by country $i$ from country $j . x_{j i, t}$ and $m_{j i, t}$ represent the reverse. $Y_{i, t}$ and $Y_{j, t}$ respectively represent the GDPs of country $i$ and country $j$ at time $t$. TS increases when the two 
countries exhibit a higher level of trade connectivity.

Equation (2), which expresses the connectivity between two countries in terms of industry, is similar in concept to the Herfindahl index in Imbs (2004). IS $S_{i, t}$ shows the degree of trade connectivity for country $i$ at time $t . I D_{i n, t}\left(I D_{j n, t}\right)$ is industry $n$ as a percentage of total industry for country $i(j)$ at time $t$. The number of $n$ is six classifications; agriculture, fishing, construction, manufacturing, wholesale and retail trade, hotels and restaurants; transport, financial intermediation, real estate, Public administration and community services, activities of households. IS increases when the two countries exhibit a higher level of industry connectivity.

Equation (3) uses the Chinn-Ito Index to indicate connectivity in the area of banking, where $B S_{i, t}$ represents the degree of banking connectivity for country $i$ at time $t$. This equation shows the average value for financial liberalization between two countries, such that $B S$ increases when the relationship is stronger.

Matrices measuring $27 \times 27$ (the EU), $10 \times 10$ (non-euro countries), and $17 \times 17$ (Eurozone countries) are developed for each indicator based on the number of countries within the three communities.

This paper focuses on the connectivity and its impact on the possibility of crisis of the 27 countries in the EU including the 17 countries of the Eurozone. It means that this paper recognizes the Eurozone as one country. The 17 countries of the Eurozone use a unitary currency and interest rate and in addition, there are no trade barriers between them. Thus, after measuring bilateral Trade Similarity (TS), bilateral Industry Similarity (IS), and bilateral Bank Similarity (BS) of individual countries of the Eurozone, we take an average so that we are able to catch out the relative level of connectivity of the Eurozone from the case of non-Euro members which are included in the membership of the EU 27.

Table 3 shows the degree of trade, industry, and banking connectivity, which is calculated by applying the variables formulated as above by using Equations (1) (3). 
Table 3. Estimation results of connectivities

\begin{tabular}{|c|c|c|c|c|c|}
\hline \multicolumn{2}{|c|}{ Sample } & \multirow{2}{*}{$\begin{array}{c}\text { EU } 27 \\
0.129 \\
(2,132)\end{array}$} & \multirow{2}{*}{$\begin{array}{c}\text { Non-euro } 10 \\
0.197 \\
(764)\end{array}$} & \multirow{2}{*}{$\begin{array}{c}\text { Euro } 17 \\
0.132 \\
(1,368)\end{array}$} & \multirow{2}{*}{$\begin{array}{c}\begin{array}{c}\text { Euro 17 } \\
\text { (After Zone) }\end{array} \\
0.186 \\
(684)\end{array}$} \\
\hline \multirow{3}{*}{$\begin{array}{c}\text { Trade } \\
\text { connectivity }\end{array}$} & Index & & & & \\
\hline & Max. & $\begin{array}{c}0.307 \\
\text { (Belgium) }\end{array}$ & $\begin{array}{c}0.456 \\
\text { (Latvia) }\end{array}$ & $\begin{array}{c}0.395 \\
\text { (Belgium) }\end{array}$ & $\begin{array}{c}0.441 \\
\text { (Belgium) }\end{array}$ \\
\hline & Min. & $\begin{array}{c}0.011 \\
\text { (Malta) }\end{array}$ & $\begin{array}{l}0.069 \\
(\mathrm{UK})\end{array}$ & $\begin{array}{c}0.013 \\
\text { (Malta) }\end{array}$ & $\begin{array}{c}0.029 \\
\text { (Malta) }\end{array}$ \\
\hline \multirow{3}{*}{$\begin{array}{c}\text { Industry } \\
\text { connectivity }\end{array}$} & Index & $\begin{array}{c}0.765 \\
(1,944)\end{array}$ & $\begin{array}{l}0.772 \\
(712)\end{array}$ & $\begin{array}{c}0.781 \\
(1,232)\end{array}$ & $\begin{array}{l}0.767 \\
(680)\end{array}$ \\
\hline & Max. & $\begin{array}{c}0.824 \\
\text { (Austria) }\end{array}$ & $\begin{array}{c}0.801 \\
\text { (Poland) }\end{array}$ & $\begin{array}{l}0.835 \\
\text { (Italy) }\end{array}$ & $\begin{array}{l}0.825 \\
\text { (Italy) }\end{array}$ \\
\hline & Min. & $\begin{array}{c}0.577 \\
\text { (Luxembourg) }\end{array}$ & $\begin{array}{c}0.689 \\
\text { (Romania) }\end{array}$ & $\begin{array}{c}0.709 \\
\text { (Luxembourg) }\end{array}$ & $\begin{array}{c}0.588 \\
\text { (Luxembourg) }\end{array}$ \\
\hline \multirow{3}{*}{$\begin{array}{c}\text { Bank } \\
\text { connectivity }\end{array}$} & Index & $\begin{array}{c}1.607 \\
(2,216)\end{array}$ & $\begin{array}{l}1.308 \\
(792)\end{array}$ & $\begin{array}{c}1.774 \\
(1,424)\end{array}$ & $\begin{array}{l}2.253 \\
(684)\end{array}$ \\
\hline & Max. & $\begin{array}{c}2.110 \\
\text { (Estonia) }\end{array}$ & $\begin{array}{c}1.947 \\
\text { (Latvia) }\end{array}$ & $\begin{array}{c}2.181 \\
\text { (Estonia) }\end{array}$ & $\begin{array}{c}2.262 \\
\text { (Austria et al.) }\end{array}$ \\
\hline & Min. & $\begin{array}{l}0.448 \\
\text { (Poland) }\end{array}$ & $\begin{array}{l}0.268 \\
\text { (Poland) }\end{array}$ & $\begin{array}{l}0.898 \\
\text { (Malta) }\end{array}$ & $\begin{array}{c}1.877 \\
\text { (Slovak Republic) }\end{array}$ \\
\hline
\end{tabular}

(Note) Average for entire period (1990:1 2011:4) and each intra-connectivity. A number of observations is given in parentheses. 'After Zone' stands for the after Euro Zone membership.

For the 27 EU countries, bilateral trade connectivity was 0.129 , bilateral industry connectivity was 0.765 , and bilateral banking connectivity was 1.607 . For non-euro countries, bilateral trade connectivity was 0.197 , a higher level than the 0.132 observed for members of the Eurozone. In particular, countries using the euro were found to have a higher degree of bilateral trade connectivity (0.186) after joining the zone, putting them roughly on par with the non-euro countries. Little difference was observed between Eurozone countries and non-euro countries in terms of bilateral industry connectivity, although the level was slightly lower for the former group after Eurozone membership. Eurozone countries had a bilateral bank connectivity rating of 1.774 , higher than the 1.308 for non-euro countries; the number increased even further to 2.253 following Eurozone membership.

Figure 1 below shows developments in the connectivity of trade, industry, and banking. 
Figure 1. Trends of connectivities

$<$ Trade $>$

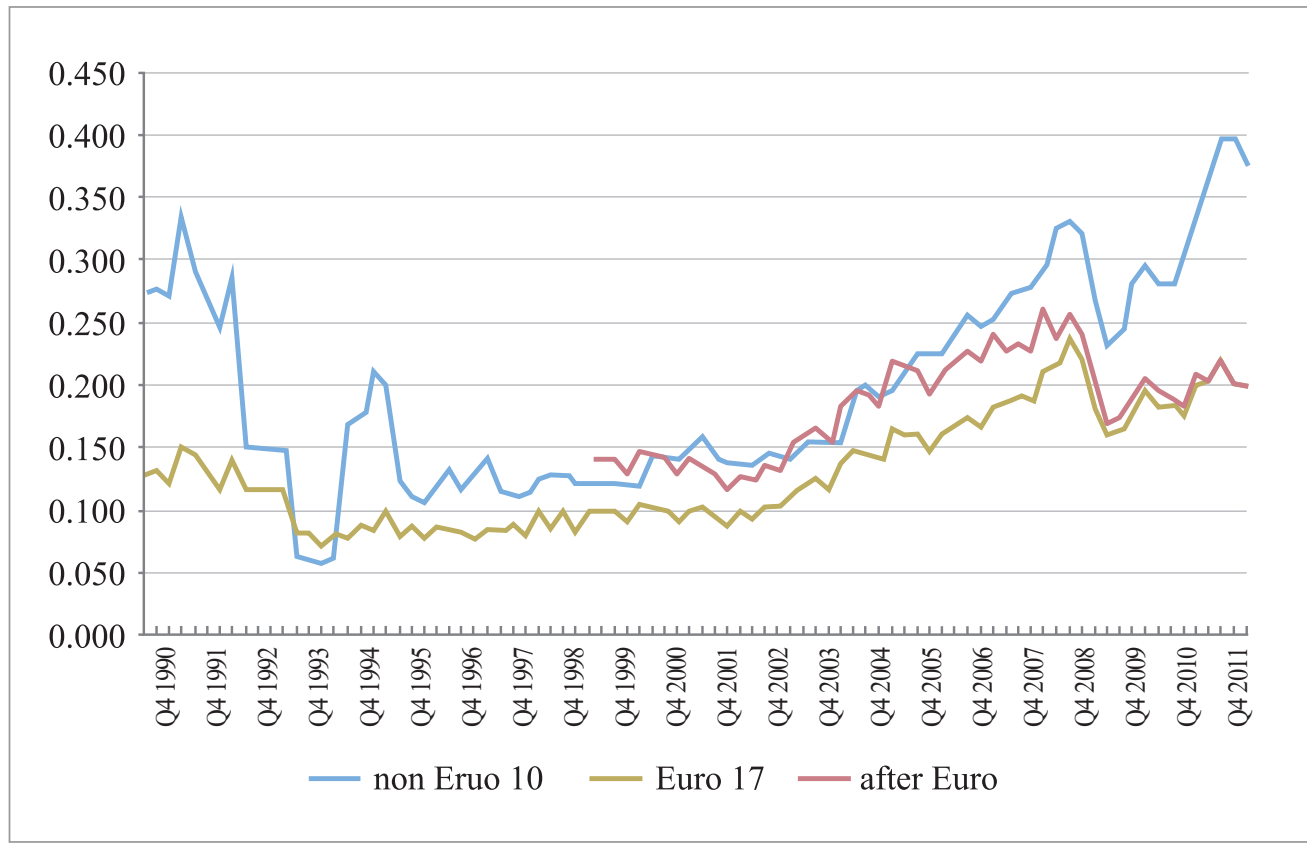

$<$ Industry $>$

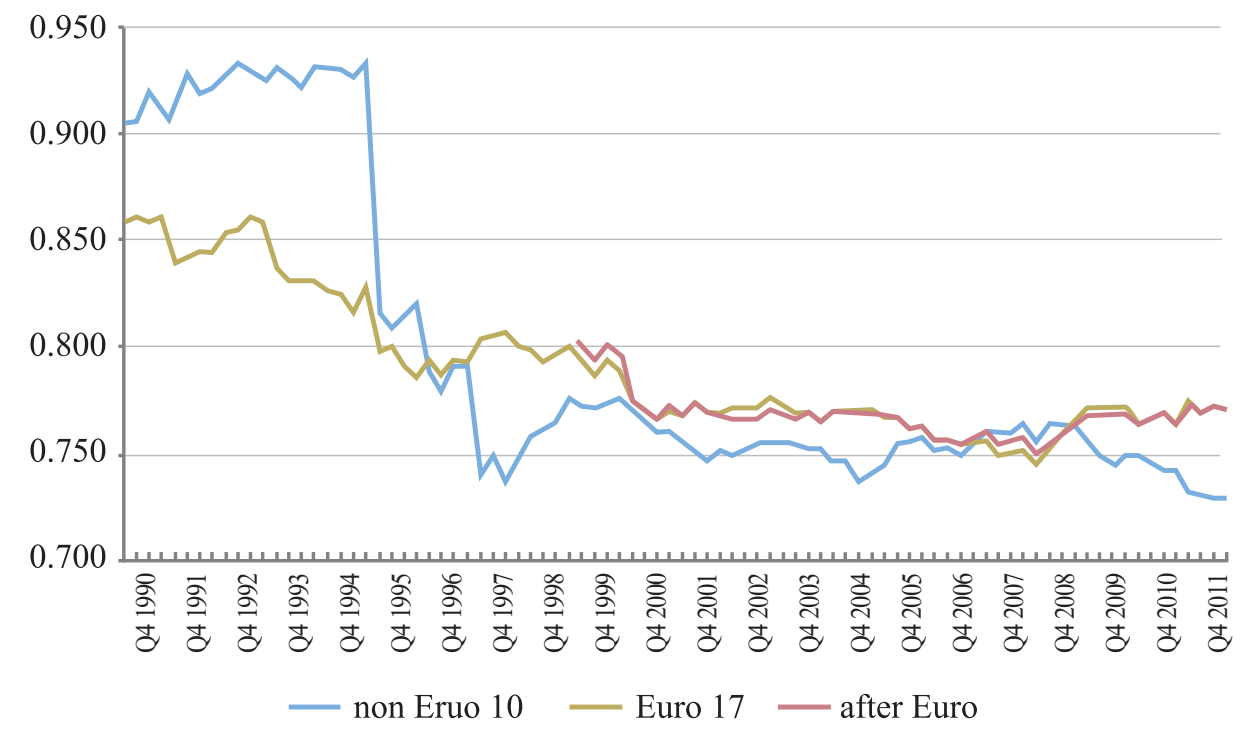




\section{$<$ Bank $>$}

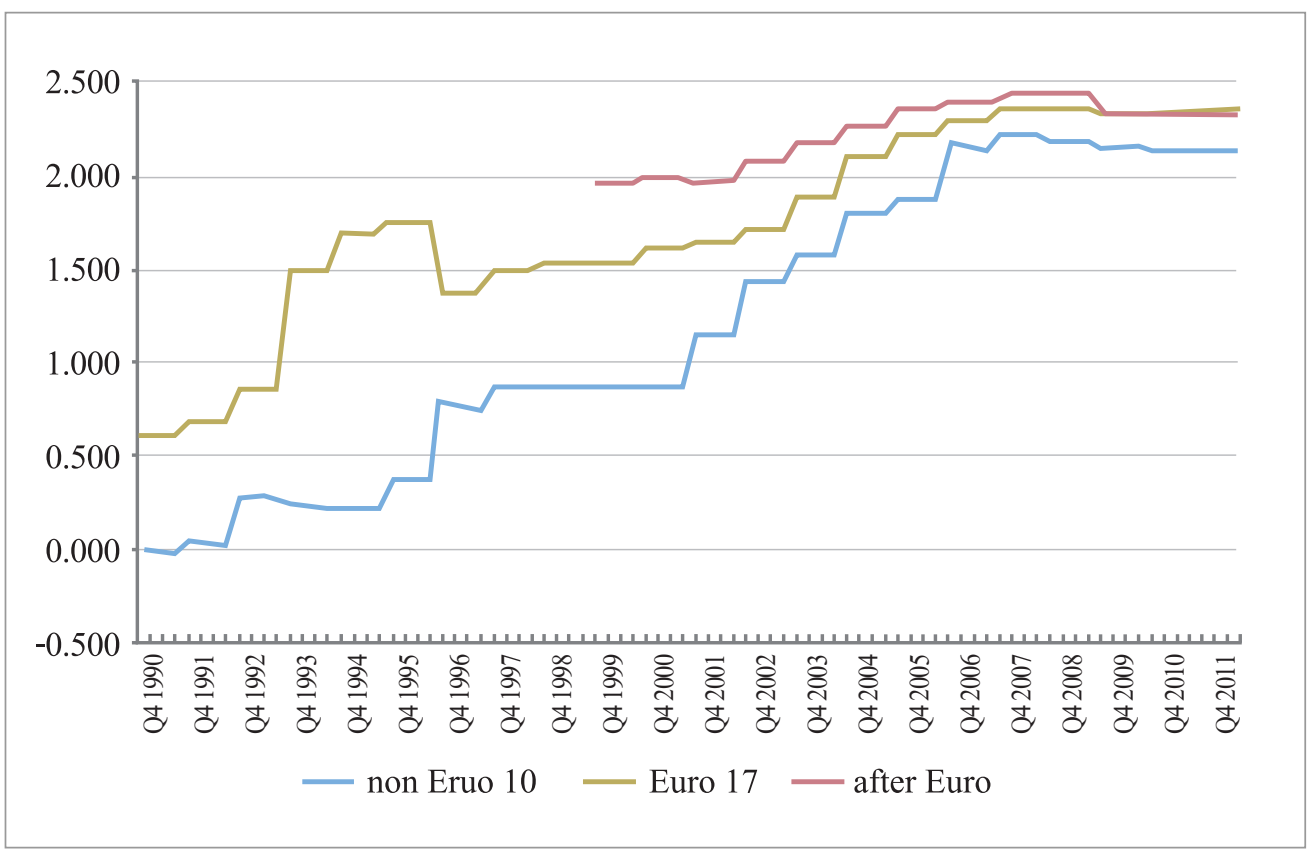

Bilateral trade connectivity was observed to increase over time, with higher levels for the 10 non-euro countries than for the 17 Eurozone members. Indeed, the gap between the two groups was found to be growing in recent years. Bilateral industry connectivity, in contrast, has been on the wane, with a larger rate of decrease for non-euro countries as compared to Eurozone members. At the same time, bilateral banking connectivity has been gradually increasing. Levels were found to be higher for countries that used the euro than for those that did not, with even higher levels after joining the zone.

What factors account for these connectivities in different sectors? The possible candidates are a very diverse lot and difficult to demonstrate conclusively. This paper focuses on an area that has been the topic of frequent discussion in recent years, namely the increasing imbalances between Eurozone countries, and in particular their disparities in terms of economic and fiscal strength and the structural changes associated with economic fluctuations.

Disparities in economic strength may give rise to phenomena of leading and following between countries, which in turn strengthen connectivity in their different sectors (Poirson and Weber 2011, Soukiazis, Cerqueira, and Antunes 2012). Differences in fiscal strength may also have a similar effect. When a country's finances become 
relatively weaker, this can lead to a greater trade imbalance with its partner (Truman 2004), with financial ties growing as the government responds to the imbalance with loans and other financial transactions with the partner nation. The strengthening of ties in each sector may also be influenced significantly by economic coordination between countries; conversely, such coordination may have an impact on connectivity in different areas (Imbs 2004, 2007).

For this paper, disparities in economic and fiscal strength and economic fluctuations are used to explain the determinants of connectivity in two countries' macroeconomic sectors. The following regression equation is applied to evaluate the relationship between the aforementioned values and sector connectivity:

$$
S_{i, t}=\alpha_{0}+\alpha_{1} B C_{i, t}+\alpha_{2} F D_{i, t}+\varepsilon_{i, t}
$$

In this equation, $S_{i, t}$ represents the sector linkages for country $i$ at time $t$, including all three areas of trade, industry, and finance. To arrive at $B C$ (which indicates economic fluctuations), periods of economic growth and decline are calculated according to the methodology in Sorensen and Yosha (2002) and Lee and Sung (2007), which use the first order difference for the log of GDP, where a value greater than zero indicates economic growth. FD represents the government's fiscal deficit, where revenues are subtracted from expenditures and divided by GDP. When an economic boom or fiscal deficit increases the connectedness between countries, the values for $\alpha_{1}$ and $\alpha_{2}$ are positive.

Table 4 below shows the results of these estimations. 
Table 4. Determinants of bilateral connectivities

\begin{tabular}{|c|c|c|c|c|c|c|}
\hline Sample & \multicolumn{3}{|c|}{ EU 27} & \multicolumn{3}{|c|}{ Non-euro 10} \\
\hline Dependent variable & $T S_{i, t}$ & $I S_{i, t}$ & $B S_{i, t}$ & $T S_{i, t}$ & $I S_{i, t}$ & $B S_{i, t}$ \\
\hline Business Cycle $_{i, t}$ & $\begin{array}{c}0.202 \\
(0.036)^{+}\end{array}$ & $\begin{array}{c}0.066 \\
(0.081)\end{array}$ & $\begin{array}{c}-2.132 \\
(0.747)^{* *}\end{array}$ & $\begin{array}{c}-0.497 \\
(0.271)^{*}\end{array}$ & $\begin{array}{c}-0.212 \\
(0.089) * *\end{array}$ & $\begin{array}{c}-4.336 \\
(1.079)^{* *}\end{array}$ \\
\hline $\begin{array}{l}\text { Fiscal Deficit } \\
(\text { GDP ratio })_{i, t}\end{array}$ & $\begin{array}{l}-0.076 \\
(0.025)^{+}\end{array}$ & $\begin{array}{c}-0.042 \\
(0.026)^{*}\end{array}$ & $\begin{array}{c}-1.049 \\
(0.240) * *\end{array}$ & $\begin{array}{c}-0.181 \\
(0.087)^{* *}\end{array}$ & $\begin{array}{c}-0.172 \\
(0.027)^{* *}\end{array}$ & $\begin{array}{c}-1.432 \\
(0.547) * *\end{array}$ \\
\hline Panel Observations & 1,554 & 1,558 & 1,578 & 583 & 575 & 583 \\
\hline$R$-squared & 0.168 & 0.193 & 0.372 & 0.175 & 0.598 & 0.437 \\
\hline Sample & \multicolumn{3}{|c|}{ Euro 17} & \multicolumn{3}{|c|}{ Euro 17 (After Zone) } \\
\hline Dependent variable & $T S_{i, t}$ & $I S_{i, t}$ & $B S_{i, t}$ & $T S_{i, t}$ & $I S_{i, t}$ & $B S_{i, t}$ \\
\hline Business Cycle $_{i, t}$ & $\begin{array}{c}0.202 \\
(0.136) * *\end{array}$ & $\begin{array}{c}0.084 \\
(0.038)^{+}\end{array}$ & $\begin{array}{c}-2.249 \\
(0.926) * *\end{array}$ & $\begin{array}{c}0.204 \\
(0.136)^{+}\end{array}$ & $\begin{array}{c}0.105 \\
(0.046) *\end{array}$ & $\begin{array}{c}0.123 \\
(0.178)\end{array}$ \\
\hline $\begin{array}{l}\text { Fiscal Deficit } \\
(\text { GDP ratio })_{i, t}\end{array}$ & $\begin{array}{c}0.010 \\
(0.042)\end{array}$ & $\begin{array}{l}-0.016 \\
(0.014)^{+}\end{array}$ & $\begin{array}{c}-0.903 \\
(0.267) * *\end{array}$ & $\begin{array}{c}-0.215 \\
(0.048)^{* *}\end{array}$ & $\begin{array}{c}0.024 \\
(0.019) *\end{array}$ & $\begin{array}{c}0.139 \\
(0.073)^{*}\end{array}$ \\
\hline Panel Observations & 971 & 983 & 995 & 684 & 680 & 684 \\
\hline$R$-squared & 0.065 & 0.072 & 0.370 & 0.051 & 0.016 & 0.710 \\
\hline
\end{tabular}

(Notes) (i) The country dummies and quarter dummies are included in all regressions but not reported.

(ii) Standard errors are given in parentheses.

(iii) + denote statistically significant at the $10 \%$ level, * denote statistically significant at the $5 \%$ level,

** denote statistically significant at the $1 \%$ level.

(iv) 'After Zone' stands for the after Euro zone membership.

Analysis of the conditions for the 27 countries of the EU showed higher levels of trade connectivity and lower levels of banking connectivity during economic boom times. Fiscal deficit conditions had a negative impact on connectivity, particularly on financial ties.

For non-euro countries, trade connectivity was observed to decline during periods of economic prosperity. For countries using the euro, however, it increased, with no change noted even after zone membership. Fiscal deficit conditions were associated with weaker levels of trade connectivity, a phenomenon that was especially salient for Eurozone countries after membership. A significant relationship was found in noneuro countries between economic fluctuations and fiscal deficit conditions on one side and industry connectivity on the other; for Eurozone countries, the relationship was not 
clearly significant. However, industry connectivity was observed to decline for noneuro countries under conditions of economic prosperity, but to increase for Eurozone countries, especially after membership. Finally, a clear difference was noted between Eurozone countries and non-euro countries in terms of trade connectivity. Financial ties between non-euro countries weakened significantly under economic boom conditions, but showed a positive relationship for countries after membership in the Eurozone. Similarly, fiscal deficit conditions weakened connectivity between non-euro countries but strengthened it for Eurozone countries, especially after membership.

The discussion so far has centered on the relationship between overall factors of economic fluctuation and fiscal deficit conditions and connectivity in macroeconomic sectors. Providing stronger support for these findings requires the development of matrix forms, in which the above factors are analyzed in terms of relationships between countries. For the purposes of this paper, relationships between countries in terms of economic fluctuations and fiscal conditions are defined as follows to provide a more robust interpretation of their relationship with sector connectivity. For economic fluctuations between countries, the traditional measure of economic coordination is used. To determine correlations, values for $\rho_{i j, t}$ that represent the economic coordination between countries $i$ and $j$ are calculated using only the fluctuations after correcting for quarterly real GDP trends. Financial relationships between countries are determined by applying the vulnerability index (De Gregorio and Valdes 2001, Baldacci, McHugh, and Petrova 2011) to the following financial variables:

$$
F V_{i, t}=\sum_{s=1}^{N}\left(\frac{F_{s i, t}-\mu}{\sigma}\right)
$$

Here, $F_{i, t}$ represents the financial variables for country $i$ at time $t$, where $s$ consists of the three variables of spending, fiscal revenues, and government debt as a percentage of GDP. Fiscal vulnerability $F V$ increases when spending and debt are positive and when revenues are negative. $\mu$ indicates the average of these variables for different countries, while $\sigma$ is the corresponding standard deviation. Applying this average and standard deviation to a country's major variables may permit an estimation of its relative vulnerability, offering a useful measure to determine weaknesses in key variables of one country compared to others in its community. 
Table 5. Estimation results of bilateral economic coordination and fiscal vulnerability

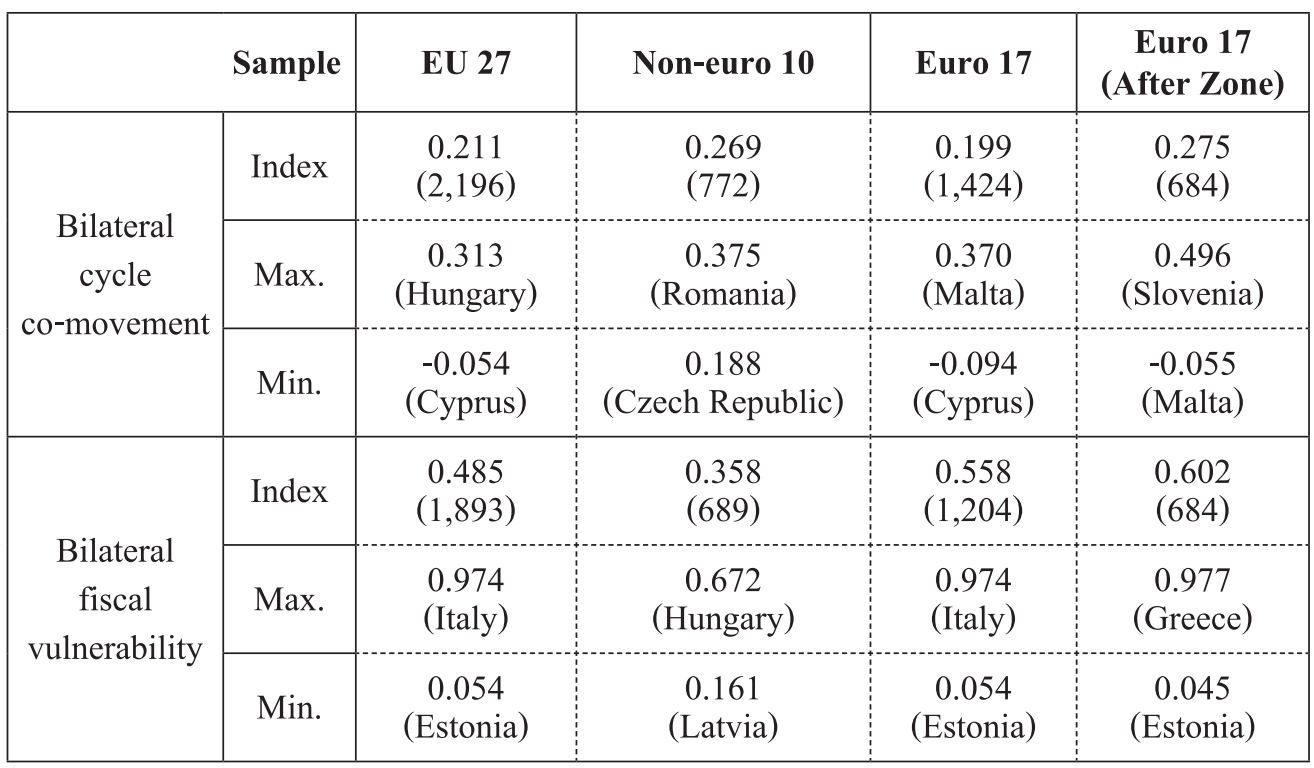

(Note) Average for entire period (1990:1 2011:4) and each intra-correlation and vulnerability. A number of observations is given in parentheses. 'After Zone' stands for the after Euro zone membership.

The economic coordination value for the 27 countries of the EU was 0.211 , with respective measures of 0.269 and 0.199 for the non-euro and Eurozone subsets. In the latter case, the level for a country was observed to rise substantially to 0.275 (a higher level than for non-euro countries) after Eurozone membership. EU countries also had a relative fiscal vulnerability rating of 0.485 . The value for Eurozone countries was 0.558 , which was higher than 0.5 and much higher than the 0.358 rating for non-euro countries. This trend was found to intensify after Eurozone membership, with fiscal vulnerability reaching a level of 0.602 . 
Figure 2. Trends of bilateral economic coordination and fiscal vulnerability

$<$ Economic coordination $>$

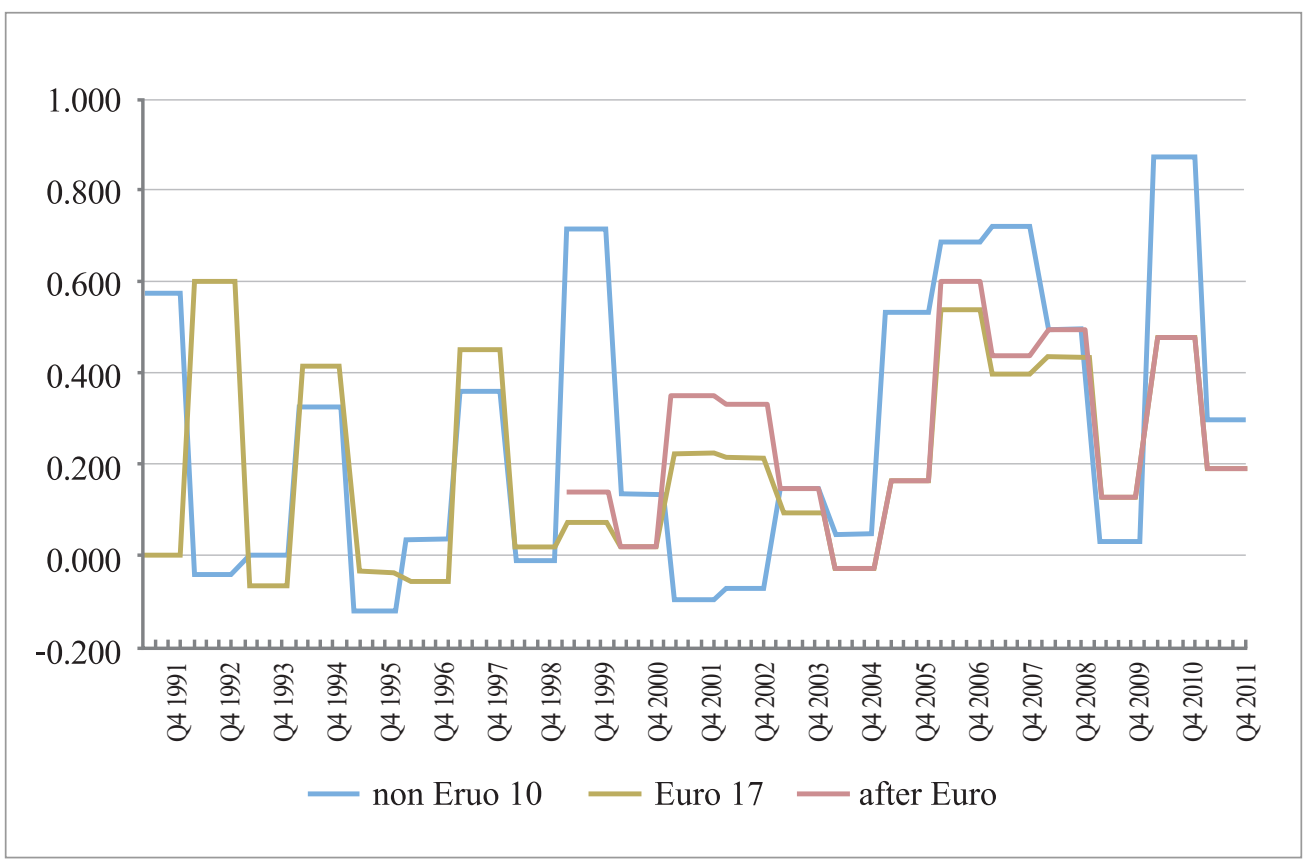

$<$ Fiscal vulnerability $>$

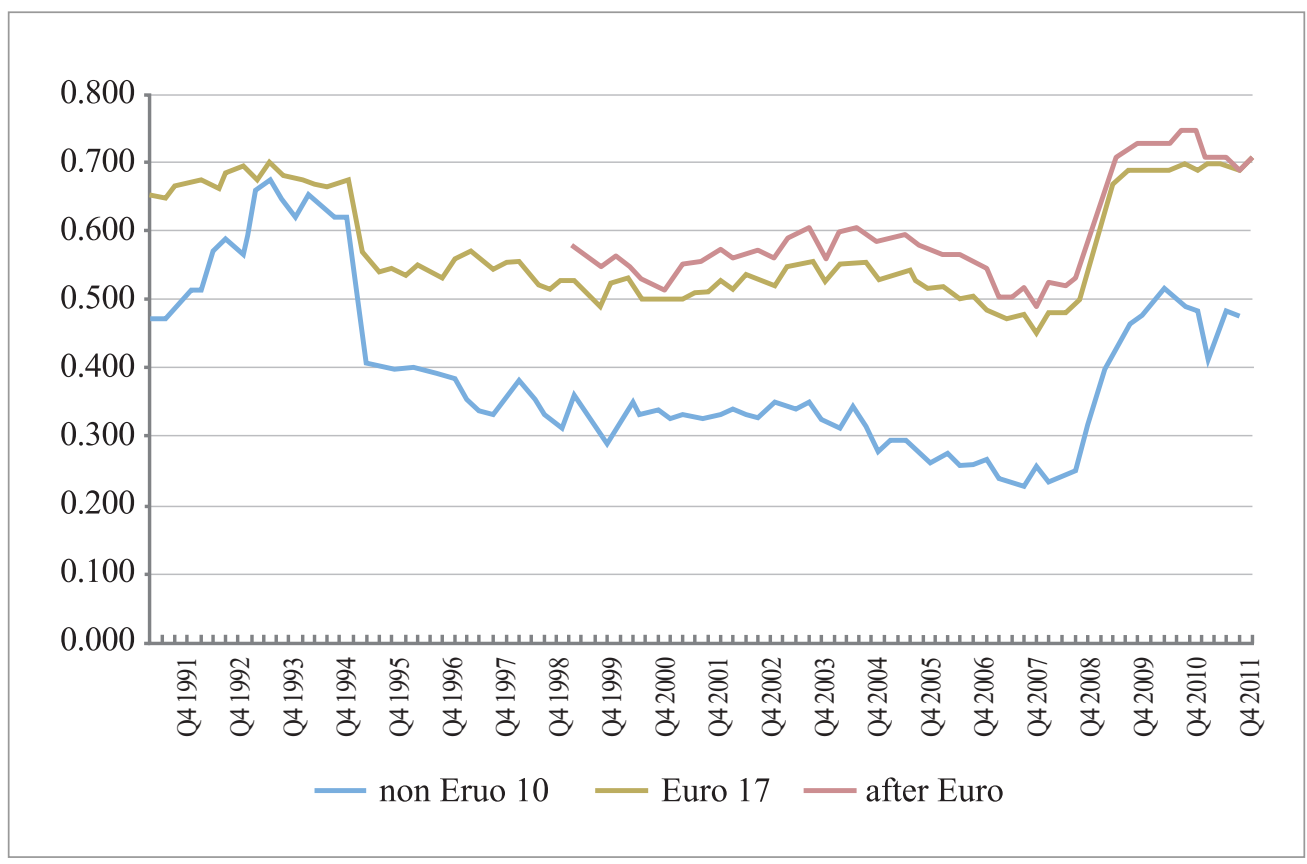


Recent years have seen economic coordination intensifying more in non-euro states than in those that use the currency. One particular noteworthy phenomenon was the weakening of this coordination between the years of 2008, when the global financial crisis erupted, and 2009. The disparity between members and non-members of the Eurozone has been widening of late. At the same time, European countries that use the euro have exhibited more fiscal vulnerability than those that do not, with a rise in vulnerability indicators dating to the time of the crisis.

For this study, measures of economic coordination and fiscal vulnerability are plugged into the following regression equation to estimate their effects on sector connectivity:

$$
S_{i, t}=\alpha_{0}^{\prime}+\alpha_{1}^{\prime} \rho_{i, t}+\alpha_{2}^{\prime} F V_{i, t}+\alpha_{3}^{\prime \prime} \Delta y_{i, t}+\varepsilon_{i, t}
$$

This equation is based on the previous Equation (4), but substitutes relative economic coordination and fiscal vulnerability between countries for overall economic fluctuations and fiscal deficit conditions in order to determine the effects of the former on connectivity between macroeconomic sectors.

Table 6 shows the results of estimations of how the economic coordination and the fiscal vulnerability index affect the connectivity of trade, industry, and banking by using Equation (6). 
Table 6. Influence on connectivities by bilateral economic coordination and fiscal vulnerability

\begin{tabular}{|c|c|c|c|c|c|c|}
\hline Sample & \multicolumn{3}{|c|}{ EU 27} & \multicolumn{3}{|c|}{ Non-euro 10} \\
\hline Dependent variable & $T S_{i, t}$ & $I S_{i, t}$ & $B S_{i, t}$ & $T S_{i, t}$ & $I S_{i, t}$ & $B S_{i, t}$ \\
\hline$\rho_{i, t}$ & $\begin{array}{c}0.003 \\
(0.002)+\end{array}$ & $\begin{array}{c}0.001 \\
(0.001)\end{array}$ & $\begin{array}{c}-0.096 \\
(0.025)^{* *}\end{array}$ & $\begin{array}{c}0.007 \\
(0.009)\end{array}$ & $\begin{array}{c}-0.005 \\
(0.003)+\end{array}$ & $\begin{array}{c}-0.130 \\
(0.059)^{*}\end{array}$ \\
\hline$F V_{i, t}$ & $\begin{array}{c}-0.026 \\
(0.006) * *\end{array}$ & $\begin{array}{c}-0.021 \\
(0.003) * *\end{array}$ & $\begin{array}{c}-0.056 \\
(0.056)\end{array}$ & $\begin{array}{c}0.044 \\
(0.014) * *\end{array}$ & $\begin{array}{c}-0.047 \\
(0.005) * *\end{array}$ & $\begin{array}{c}-0.307 \\
(0.099) * *\end{array}$ \\
\hline$\Delta y$ per capita $_{i, t}$ & $\begin{array}{c}-0.018 \\
(0.012)+\end{array}$ & $\begin{array}{l}-0.003 \\
(0.006)\end{array}$ & $\begin{array}{c}0.188 \\
(0.121)+\end{array}$ & $\begin{array}{c}-0.045 \\
(0.026)+\end{array}$ & $\begin{array}{l}-0.006 \\
(0.009)\end{array}$ & $\begin{array}{c}0.053 \\
(0.175)\end{array}$ \\
\hline Panel Observations & 1,844 & 1,796 & 1,854 & 684 & 674 & 672 \\
\hline$R$-squared & 0.219 & 0.101 & 0.363 & 0.157 & 0.514 & 0.457 \\
\hline Sample & \multicolumn{3}{|c|}{ Euro 17} & \multicolumn{3}{|c|}{ Euro 17 (After Zone) } \\
\hline Dependent variable & $T S_{i, t}$ & $I S_{i, t}$ & $B S_{i, t}$ & $T S_{i, t}$ & $I S_{i, t}$ & $B S_{i, t}$ \\
\hline$\rho_{i, t}$ & $\begin{array}{l}-0.001 \\
(0.006)\end{array}$ & $\begin{array}{c}-0.004 \\
(0.002)^{*}\end{array}$ & $\begin{array}{c}-0.050 \\
(0.038)+\end{array}$ & $\begin{array}{c}-0.019 \\
(0.007) * *\end{array}$ & $\begin{array}{c}-0.006 \\
(0.002) *\end{array}$ & $\begin{array}{c}-0.005 \\
(0.011)\end{array}$ \\
\hline$F V_{i, t}$ & $\begin{array}{c}-0.092 \\
(0.012)^{*} *\end{array}$ & $\begin{array}{c}0.002 \\
(0.004)\end{array}$ & $\begin{array}{c}0.179 \\
(0.072)^{* *}\end{array}$ & $\begin{array}{c}-0.080 \\
(0.015) * *\end{array}$ & $\begin{array}{c}0.007 \\
(0.006)\end{array}$ & $\begin{array}{c}-0.042 \\
(0.023)+\end{array}$ \\
\hline$\Delta y$ per $_{\text {capita }}{ }_{i, t}$ & $\begin{array}{c}-0.008 \\
(0.036)\end{array}$ & $\begin{array}{c}0.009 \\
(0.012)\end{array}$ & $\begin{array}{c}0.453 \\
(0.222)^{*}\end{array}$ & $\begin{array}{c}0.001 \\
(0.033)\end{array}$ & $\begin{array}{c}0.016 \\
(0.013)\end{array}$ & $\begin{array}{l}-0.010 \\
(0.051)\end{array}$ \\
\hline Panel Observations & 1,160 & 1,122 & 1,182 & 684 & 680 & 684 \\
\hline$R$-squared & 0.012 & 0.120 & 0.338 & 0.005 & 0.039 & 0.705 \\
\hline
\end{tabular}

(Notes) (i) The country dummies and quarter dummies are included in all regressions but not reported.

(ii) Standard errors are given in parentheses.

(iii) + denote statistically significant at the $10 \%$ level, * denote statistically significant at the $5 \%$ level, ** denote statistically significant at the $1 \%$ level.

(iv) 'After Zone' stands for the after Euro zone membership.

In the case of the 27 nations of the EU, economic coordination was found to be fairly but not extremely strong in terms of trade connectivity, and to have a negative impact on banking connectivity. Indeed, negative effects were observed in all areas of linkage when fiscal conditions were relatively weak.

For non-euro countries, economic coordination is observed to increase trade linkages, but the opposite phenomenon is found for countries that use the euro, especially after membership. For industry connectivity, the effects are negative for Eurozone and non- 
Eurozone countries alike. It also results in a lower degree of banking connectivity for both groups, though this is observed to reverse itself somewhat after membership in the Eurozone. In contrast, countries that did and did not use the euro exhibit diametrically opposing results in terms of the effects of fiscal vulnerability on sector connectivity. Relative vulnerability has a strongly negative influence on trade connectivity for Eurozone countries, but a positive one for non-euro countries. This strongly suggests that trade imbalances resulting from relative fiscal vulnerability have affected trade connectivity between countries that use the euro as a common currency. Also, this vulnerability is found to reduce banking connectivity for non-euro countries while increasing it for Eurozone members, although the relationship is observed to be negative after Eurozone membership. This can be interpreted in several ways, but it appears to reflect the combined influence of weakened fiscal conditions, deepening imbalances in fiscal strength, and banking crisis conditions in the Eurozone as countries with strong financial ties in the early period after integration with the euro experienced conditions of financial crisis.

\section{B. Bilateral connectivity's influences on the possibility of crisis}

A variety of tools are available for examining or predicting a particular country's crisis conditions. These include the Fiscal Stress Test, the CCI, and the Financial Condition Index (Frankel and Rose 1996, Van den End 2006). For this paper, the CCI will be applied, which uses currency rate fluctuations and differences in interest rates and foreign reserves between countries to judge the possibility of a crisis occurring, was deemed best suited for an analysis of the Eurozone countries that already adopted the same currency and interest rates, resulting in an effective absence of trade barriers.

The CCI reflects continuous foreign exchange market pressures due to changes in currency rates, interest rates, and foreign reserves. It can be defined as follows (Fratzscher 2000):

$$
C C I_{i, t}=\eta\left(\Delta e_{i, t}\right)+\varphi\left(\Delta\left(i_{i, t}-i_{U S, t}\right)\right)-\psi\left(\Delta R_{i, t}\right)
$$

In this equation, $\Delta e_{i, t}$ indicates the variation in country $i$ 's exchange rate at time $t$, while $i$ and $i_{U S}$ represent the respective interest rates of the country and the US and $R$ represents the country's foreign reserves. The weighted values of $\eta, \varphi$, and $\psi$ are defined 
as the reciprocals of the standard deviation for the time series of each variable. As such, $\mathrm{CCI}$ rises when currency rate fluctuations and the difference in interest rates between the country and the US. market grow while foreign reserves drop. Crucially, this calculation requires standardization to apply CCI levels for different countries (reflecting the time series and cross-section) to the model for empirical analysis. Standardization is necessary because both CCI and the subsequently-developed Fiscal Vulnerability Index (FVI) provide measures of the vulnerability of certain nations relative to others (Sachs, Tornell, and Velasco 1996, Eichengreen, Rose, and Wyplosz 1997). Hence, the estimated CCI, and the subsequent estimated FVI are all transformed cumulative normal distribution, ranging from 0 to 1 , with a mean of 0.5 index. Index values close to 1 indicate high levels of current crisis.

In order words, CCI shows the possibility of the outbreak of a currency crisis, and as its figure grows, i.e., close to 1 , there is higher possibility of a currency crisis. Volatility of exchange rates, interest rate differentials with other countries, and the growth rate of foreign currency reserves are the main factors of CCI. It implies that if the volatility of exchange rates and the interest rate differential grow, and as there is a sharp decline of foreign currency reserves, then the CCI will increase and with it the possibility of a currency crisis.

Table 7 below shows the results of CCI estimations by using Equation (7).

Table 7. Estimation results of currency crisis index

\begin{tabular}{|c|c|c|c|c|}
\hline Sample & EU 27 & Non-euro 10 & Euro 17 & Euro 17 (After Zone) \\
\hline Index & $\begin{array}{c}0.402 \\
(2,043)\end{array}$ & $\begin{array}{c}0.464 \\
(673)\end{array}$ & $\begin{array}{c}0.379 \\
(1,370)\end{array}$ & $\begin{array}{c}0.334 \\
(684)\end{array}$ \\
\hline Max. & $\begin{array}{c}0.562 \\
\text { (Bulgaria) }\end{array}$ & $\begin{array}{c}0.562 \\
\text { (Bulgaria) }\end{array}$ & $\begin{array}{c}0.489 \\
\text { (Malta) }\end{array}$ & $\begin{array}{c}0.435 \\
\text { (Finland) }\end{array}$ \\
\hline Min. & $\begin{array}{c}0.114 \\
\text { (Luxembourg) }\end{array}$ & $\begin{array}{c}0.365 \\
(\mathrm{UK})\end{array}$ & $\begin{array}{c}0.114 \\
\text { (Luxembourg) }\end{array}$ & $\begin{array}{c}0.133 \\
\text { (Greece) }\end{array}$ \\
\hline
\end{tabular}

(Note) Average for entire period (1990:1 2011:4). A number of observations is given in parentheses. 'After Zone' stands for the after Euro zone membership.

For the 27 countries of the EU, the CCI was 0.402 . Since this level was below 0.5 , it suggests that the possibility of a currency crisis is less than average. When the countries 
were divided into the 17 that use the euro and the 10 that do not, the latter group was found to have a CCI of 0.464 , which is higher than the former's figure of 0.379 . This indicates that non-euro countries are at a higher risk of a currency crisis than Eurozone countries. The level was also found to decrease after Eurozone membership. This appears to be the result of efforts by the countries that use the Euro to eliminate risks through currency integration. However, it is impossible to state with any certainty that such efforts actually succeed in continuously lowering the possibility of a currency crisis for the countries that use the euro. Early on after the Eurozone was established, the use of a common currency and common interest rates may well have had some effect in this regard, but experiences with financial crisis in the mid-2000s and the global crisis of 2008 2009 appears to have changed the situation.

Figure 3 below shows developments in the estimated CCI.

\section{Figure 3. Trends of currency crisis index}

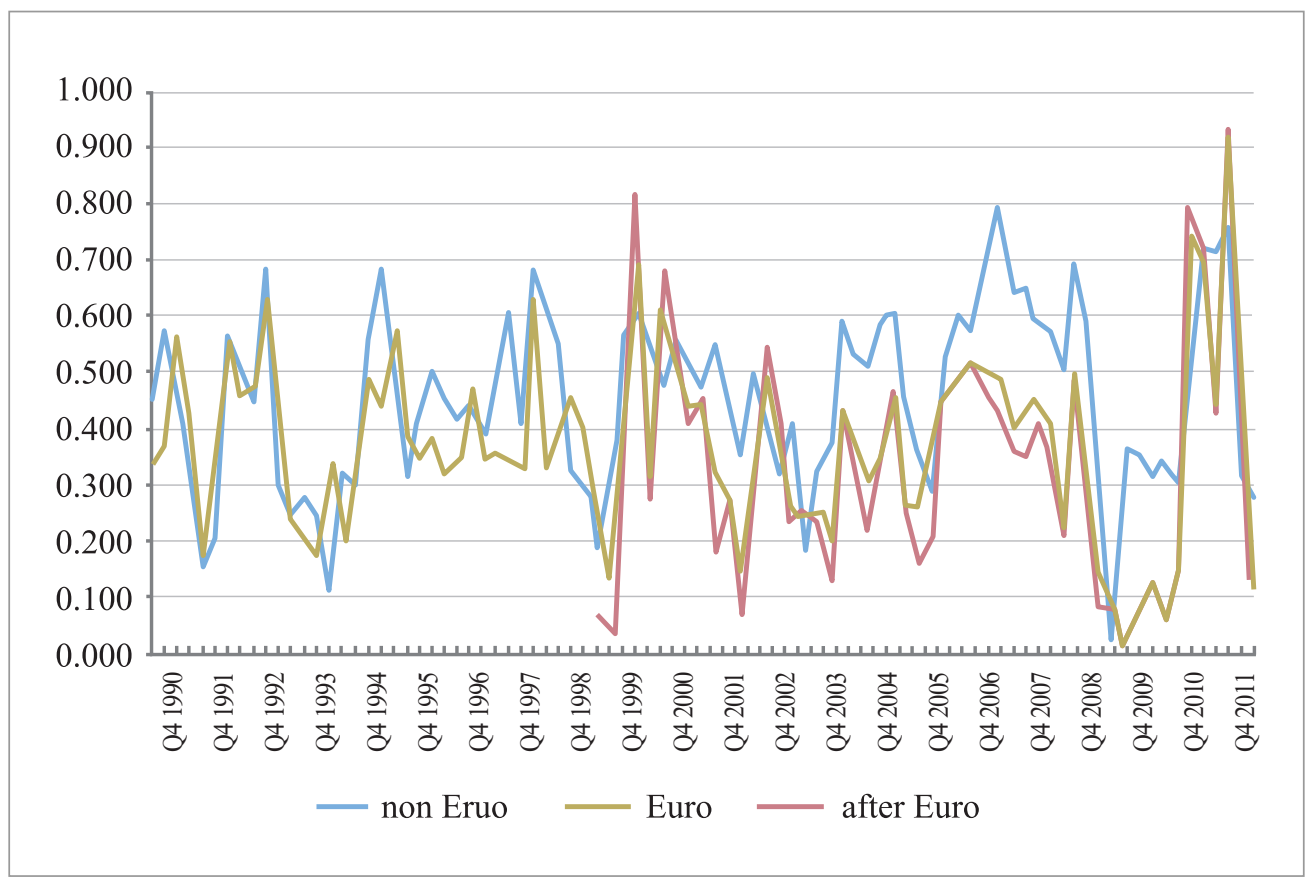

The CCI for countries that have adopted the euro has been dropping since the zone's establishment in 1999. The decrease has been especially pronounced in comparison with the non-euro countries, particularly in the years 2008 and 2009. This appears to be the 
result of efforts by different countries to adopt a different approach of proactive currency issuance and low interest rates in response to the aforementioned crises. However, the countries of the Eurozone experienced a sharp rise in CCI with the first quarter of 2010, passing the non-euro countries on their way to a recent level of almost 1.0. Figure 3 shows how the risk reduction effect of the Eurozone's integration has dropped substantially in recent years.

To what factors can the observed CCI levels be attributed? Prior to any estimation of the relationship between sector connectivities and CCI, the following equation was used to give an overall indication of the relationships between CCI and the different constituent variables in sector connectivity.

$$
C C I_{i, t}=\beta_{0}+\beta_{1} T_{-} \text {deficit }_{i, t-1}+\beta_{2} G V A_{i, t-1}+\beta_{3} F_{-} \text {openness }_{i, t-1}+\beta_{4} \Delta y_{i, t}+\varepsilon_{i, t}
$$

In this equation, $T$ deficit ${ }_{i, t-1}$ shows the trade deficit (imports minus exports) relative to GDP for country $i$. The scale of deficit here differs according to the economic community with which a given country is affiliated: for EU members, it indicates the size of the trade deficit with other countries in the union, while for non-euro and Eurozone countries, it indicates deficits with other countries in their respective group. $G V A_{i, t-1}$ represents total value added relative to GDP for country $i$ at time $t-1$. F_openness s.t-1 $_{1}$ is country $i$ 's score on the fiscal openness (Chinn-Ito) index at time $t-1$, while $\Delta y_{i, t}$ is the GDP per capita growth rate for country $i$ at time $t$, which is included as a control variable for country scale. The purpose of this equation is to estimate the effect of the different constituent variables of each sector of trade, industry, and finance on CCI prior to calculating the relationship between connectivities in those sectors and CCI. If trade deficit conditions do amplify the risk of a currency crisis, then value $\alpha_{1}$ will be positive; if the risk decreases with higher levels of value added or financial liberalization, then $\alpha_{2}$ and $\alpha_{3}$ will be negative.

Table 8 shows the variables that determine CCI by using Equation (8). 
Table 8. Determinants of currency crisis index

\begin{tabular}{|c|c|c|c|c|}
\hline Dependent variable & & & & \\
\hline Sample & EU 27 & Non-euro 10 & Euro 17 & $\begin{array}{c}\text { Euro 17 } \\
\text { (After Zone) }\end{array}$ \\
\hline $\begin{array}{l}\text { Trade Deficit }_{i, t-1} \\
\text { (GDP ratio) }\end{array}$ & $\begin{array}{c}0.182 \\
(0.191)\end{array}$ & $\begin{array}{l}-1.457 \\
(1.455)\end{array}$ & $\begin{array}{c}0.853 \\
(0.310)^{* *}\end{array}$ & $\begin{array}{c}1.011 \\
(0.420)^{* *}\end{array}$ \\
\hline$G V A_{i, t-1}($ GDP ratio $)$ & $\begin{array}{c}-0.140 \\
(0.084)^{+}\end{array}$ & $\begin{array}{l}-0.126 \\
(0.199)\end{array}$ & $\begin{array}{l}-0.271 \\
(0.119)^{*}\end{array}$ & $\begin{array}{l}-0.275 \\
(0.394)\end{array}$ \\
\hline $\begin{array}{c}\text { Financial Openness } \\
\text { Index }_{i, t} \\
\end{array}$ & $\begin{array}{l}-0.010 \\
(0.009)\end{array}$ & $\begin{array}{l}-0.001 \\
(0.018)\end{array}$ & $\begin{array}{l}-0.032 \\
(0.011)^{* *}\end{array}$ & $\begin{array}{c}-0.027 \\
(0.045)\end{array}$ \\
\hline$\Delta y$ per capita ${ }_{i, t}$ & $\begin{array}{l}-0.058 \\
(0.089) \\
\end{array}$ & $\begin{array}{c}-0.141 \\
(0.151) \\
\end{array}$ & $\begin{array}{c}0.149 \\
(0.139) \\
\end{array}$ & $\begin{array}{c}0.234 \\
(0.261) \\
\end{array}$ \\
\hline Panel Observations & 1,819 & 621 & 1,198 & 677 \\
\hline$R$-squared & 0.289 & 0.225 & 0.447 & 0.638 \\
\hline
\end{tabular}

(Notes) (i) The country dummies and quarter dummies are included in all regressions but not reported.

(ii) Standard errors are given in parentheses.

(iii) + denote statistically significant at the $10 \%$ level, * denote statistically significant at the $5 \%$ level,

** denote statistically significant at the $1 \%$ level.

(iv) 'After Zone' stands for the after Euro zone membership.

For the 27 countries of the EU, CCI was consistently observed to decrease with higher levels of total value added relative to GDP. No correlation was found between CCI and trade, industry, and banking variables for the 10 non-euro countries. However, a statistically significant relationship was observed for the 17 countries that use the euro. This bears out the conventional expectation that the risk of a currency crisis would rise with a higher trade deficit, while the CCI would be lower with higher levels of industry value added and financial liberalization. Similarly, the expected relationship between the three variables and CCI was detected for the Eurozone countries after membership, albeit with a slight difference: trade deficit conditions were found to have a stronger effect in increasing the CCI, while percentage of value added and degree of financial liberalization had an inversely proportional impact on it.

The next question has to do with the relationship between CCI and country-tocountry connectivity in trade, industry, and finance, and specifically whether increased connectivity leads to a greater or lesser likelihood of crisis. For this study, sector connectivity is applied to Equation (8) to produce the following regression equation: 


$$
C C I_{i, t}=\beta_{0}^{\prime}+\beta_{1}^{\prime} T S_{i, t}+\beta_{2}^{\prime} I S_{i, t}+\beta_{3}^{\prime} B S_{i, t}+\beta_{4}^{\prime} \Delta y_{i, t}+\varepsilon_{i, t}
$$

Equation (9) estimates the relationship between connectivity and CCI, taking into account the three sectors of trade (TS), industry (IS), and banking (BS), as connectivity in these areas is viewed as likely to have a mutual impact. For example, when two nations have a high degree of trade connectivity but a low degree of industry connectivity, trade generally takes place between different industries. Conversely, when both trade and industry connectivity are high, trade takes place in similar industries. Banking connectivity may increase between two countries as a safeguard against the uncertainties that arise from transactions based in trade and industry connectivity. Thus, the above equation takes into account connectivity in all three areas to gauge their impact on the likelihood of a currency crisis as measured by the CCI. If trade, industry, and banking connectivity increase the chances of a currency crisis occurring, then the values for $\beta_{1}^{\prime}, \beta_{2}^{\prime}$, and $\beta_{3}^{\prime}$ should be positive.

Table 9 shows the results of these estimations.

Table 9. Influence on currency crisis index by bilateral connectivities

\begin{tabular}{|c|c|c|c|c|}
\hline Dependent variable & \multicolumn{4}{|c|}{$C C I_{i t}$} \\
\hline Sample & EU 27 & Non-euro 10 & Euro 17 & $\begin{array}{c}\text { Euro 17 } \\
\text { (After Zone) }\end{array}$ \\
\hline$T S_{i, t}$ & $\begin{array}{c}0.196 \\
(0.161)\end{array}$ & $\begin{array}{c}0.329 \\
(0.280)\end{array}$ & $\begin{array}{c}0.231 \\
(0.113)^{*}\end{array}$ & $\begin{array}{c}0.828 \\
(0.132)^{* *}\end{array}$ \\
\hline$I S_{i, t}$ & $\begin{array}{c}-0.537 \\
(0.265)^{*}\end{array}$ & $\begin{array}{c}0.014 \\
(0.520)\end{array}$ & $\begin{array}{c}-1.740 \\
(0.355) * *\end{array}$ & $\begin{array}{c}-2.630 \\
(0.327)^{* *}\end{array}$ \\
\hline$B S_{i, t}$ & $\begin{array}{l}-0.003 \\
(0.017)\end{array}$ & $\begin{array}{c}-0.002 \\
(0.035)\end{array}$ & $\begin{array}{c}-0.027 \\
(0.020)^{+}\end{array}$ & $\begin{array}{c}-0.192 \\
(0.087)^{*}\end{array}$ \\
\hline$\Delta y$ per capita ${ }_{i, t}$ & $\begin{array}{c}-0.157 \\
(0.083) *\end{array}$ & $\begin{array}{c}-0.224 \\
(0.128)^{+}\end{array}$ & $\begin{array}{c}0.184 \\
(0.136)^{+}\end{array}$ & $\begin{array}{c}0.331 \\
(0.108)^{* *}\end{array}$ \\
\hline Panel Observations & 1,794 & 623 & 1,171 & 680 \\
\hline$R$-squared & 0.275 & 0.259 & 0.264 & 0.294 \\
\hline
\end{tabular}

(Notes) (i) The country dummies and quarter dummies are included in all regressions but not reported.

(ii) Standard errors are given in parentheses.

(iii) + denote statistically significant at the 10\% level, *denote statistically significant at the 5\% level, ** denote statistically significant at the $1 \%$ level.

(iv) 'After Zone' stands for the after Euro zone membership. 
The 27 countries of the EU show a decreasing likelihood of currency crisis with higher levels of industry connectivity between countries. This likelihood is also observed to drop at higher GDP per capita growth rates. No statistically significant relationship is observed between connectivity and currency crisis likelihood for the 10 non-euro countries, but a strongly significant one is found in the case of the Eurozone countries. In particular, connectivity in the areas of industry and banking is seen to decrease the chances of a currency crisis, while connectivity in the area of trade is seen to increase them. A significant positive relationship is also found between GDP per capita growth rate and the possibility of crisis, a trend that is observed to increase after Eurozone membership. This indicates that connectivity in industry and finance lowers the likelihood of crisis, while trade connectivity increases it.

Taken together, these findings show that countries that use the euro as a common currency face an increased risk of currency crisis with high levels of trade connectivity based in regional transactions. In other words, while trade linkages have grown stronger between Eurozone members as a result of local transactions, where trade barriers have been minimized to increase relative gains and reduce uncertainty, this connectivity has actually had the effect of exposing them to a greater crisis risk.

Another question to consider is what effect economic coordination and relative fiscal vulnerability have on the likelihood of a currency crisis occurring, as well as what impact these have on the relationship between sector connectivity and CCI. For this study, the following regression equation is used to calculate $\mathrm{CCI}$ :

$$
C C I_{i, t}=\beta_{0}^{\prime}+\beta_{1}^{\prime \prime} \rho_{i, t}+\beta_{2}^{\prime \prime} F V_{i, t}+\beta_{3}^{\prime \prime} T S_{i, t}+\beta_{4}^{\prime \prime} I S_{i, t}+\beta_{5}^{\prime \prime} B S_{i, t}+\beta_{6}^{\prime \prime} \Delta y_{i, t}+\varepsilon_{i, t}
$$

Equation (10) observes the change when economic coordination and relative fiscal vulnerability are factored into Equation (9).

Table 10 shows the results of these estimations. 
Table 10. Influence on Currency Crisis Index by bilateral economic coordination and fiscal vulnerability

\begin{tabular}{|c|c|c|c|c|}
\hline \multirow{2}{*}{$\begin{array}{r}\text { Dependent variable } \\
\text { Sample }\end{array}$} & \multicolumn{4}{|c|}{$C C I_{i t}$} \\
\hline & EU 27 & Non-euro 10 & Euro 17 & $\begin{array}{c}\text { Euro 17 } \\
\text { (After Zone) }\end{array}$ \\
\hline$\rho_{i, t}$ & $\begin{array}{c}0.026 \\
(0.023)\end{array}$ & $\begin{array}{c}0.058 \\
(0.046)\end{array}$ & $\begin{array}{c}0.012 \\
(0.024)\end{array}$ & $\begin{array}{c}0.050 \\
(0.023) *\end{array}$ \\
\hline$F V_{i, t}$ & $\begin{array}{c}-0.096 \\
(0.043)^{*}\end{array}$ & $\begin{array}{l}-0.084 \\
(0.080)\end{array}$ & $\begin{array}{l}-0.022 \\
(0.050)\end{array}$ & $\begin{array}{c}0.005 \\
(0.051)\end{array}$ \\
\hline$T S_{i, t}$ & $\begin{array}{c}0.154 \\
(0.166)\end{array}$ & $\begin{array}{c}0.337 \\
(0.286)\end{array}$ & $\begin{array}{c}0.257 \\
(0.120)^{*}\end{array}$ & $\begin{array}{c}0.859 \\
(0.135)^{* *}\end{array}$ \\
\hline$I S_{i, t}$ & $\begin{array}{c}-0.656 \\
(0.318)^{*}\end{array}$ & $\begin{array}{c}0.089 \\
(0.646)\end{array}$ & $\begin{array}{c}-1.860 \\
(0.368)^{* *}\end{array}$ & $\begin{array}{c}-2.584 \\
(0.328)^{* *}\end{array}$ \\
\hline$B S_{i, t}$ & $\begin{array}{l}-0.006 \\
(0.018)\end{array}$ & $\begin{array}{l}-0.006 \\
(0.035)\end{array}$ & $\begin{array}{c}-0.028 \\
(0.021)^{+}\end{array}$ & $\begin{array}{c}-0.191 \\
(0.087)^{*}\end{array}$ \\
\hline$\Delta y$ per capita $_{i, t}$ & $\begin{array}{c}-0.191 \\
(0.089) *\end{array}$ & $\begin{array}{c}-0.286 \\
(0.139) *\end{array}$ & $\begin{array}{c}0.168 \\
(0.138)\end{array}$ & $\begin{array}{c}0.312 \\
(0.109)^{* *}\end{array}$ \\
\hline Panel Observations & 1,680 & 598 & 1,082 & 680 \\
\hline$R$-squared & 0.264 & 0.274 & 0.239 & 0.303 \\
\hline
\end{tabular}

(Notes) (i) The country dummies and quarter dummies are included in all regressions but not reported.

(ii) Standard errors are given in parentheses.

(iii) + denote statistically significant at the $10 \%$ level, * denote statistically significant at the $5 \%$ level, ** denote statistically significant at the $1 \%$ level.

(iv) 'After Zone' stands for the after Euro zone membership.

The results in terms of the relationship between trade, industry, and banking connectivity and CCI for each group do not exhibit much of a difference from the previous figures in Table 6; on the whole, the relationship is found to decrease slightly. In most of the groups, a positive, though not statistically significant, relationship is found between coordination and CCI. For Eurozone countries, however, the likelihood of a crisis occurring is seen to increase with a higher degree of economic coordination after joining the zone. No strongly significant relationship is found between fiscal vulnerability and CCI either.

Next, we turn to the effect on CCI when economic coordination and relative fiscal vulnerability combine with sector connectivity. The question here is what contribution these factors between countries make to the effect of sector connectivity on CCI. For this study, the following equation is used to examine the path by which economic 
coordination and relative fiscal vulnerability interact with sector connectivity to influence CCI:

$$
C C I_{i, t}=\delta+\gamma_{t} S_{i, t}+\varepsilon_{i, t}
$$

Equation (11) estimates how vulnerability affects CCI as above using Equation (8) (10). Here, coefficient $\gamma_{t}$ measures the relationship between CCI and connectivity over time. To access the contribution of economic coordination or fiscal vulnerability, the time varying coefficient $\gamma_{t}$ is specified as a function of time and the dispersion of economic coordination or fiscal vulnerability.

$$
\gamma_{t}=\gamma_{0}+\gamma_{1} t+\gamma_{2} \rho_{i, t}\left(F V_{i, t}\right)+\varepsilon_{i, t}
$$

Substituting Equation (12) into Equation (11) results in:

$$
\begin{gathered}
C C I_{i, t}=\delta+\gamma_{0} S_{i, t}+\gamma_{1} t S_{i, t}+\gamma_{2} \rho_{i, t} S_{i, t}+\varepsilon_{i, t} \\
C C I_{i, t}=\delta^{\prime}+\gamma_{0}^{\prime} S_{i, t}+\gamma_{1}^{\prime} t S_{i, t}+\gamma_{2}^{\prime} F V_{i, t} S_{i, t}+\varepsilon_{i, t}
\end{gathered}
$$

The coefficient $\gamma_{0}\left(\gamma_{0}^{\prime}\right)$ measures the relationship between CCI and connectivity, $\gamma_{1}\left(\gamma_{1}^{\prime}\right)$ indicates how the relationship evolves overtime, and $\gamma_{2}\left(\gamma_{2}^{\prime}\right)$ captures the effect of economic coordination or fiscal vulnerability.

Table 11 below presents the estimated results of how economic coordination affects the relationship between connectivity and CCI by using Equation (13). 
Table 11. Channels influence on Currency Crisis Index by bilateral economic coordination

\begin{tabular}{|c|c|c|c|c|}
\hline Dependent variable & \multicolumn{4}{|c|}{$C C I_{i t}$} \\
\hline Sample & EU 27 & Non-euro 10 & Euro 17 & $\begin{array}{c}\text { Euro 17 } \\
\text { (After Zone) }\end{array}$ \\
\hline$\rho_{i, t}$ & $\begin{array}{l}-0.005 \\
(0.080)\end{array}$ & $\begin{array}{c}0.033 \\
(0.527)\end{array}$ & $\begin{array}{l}-0.033 \\
(0.082)\end{array}$ & $\begin{array}{l}-0.006 \\
(0.310)\end{array}$ \\
\hline Time varying $\times \rho_{i, t}$ & $\begin{array}{c}0.001 \\
(0.001)\end{array}$ & $\begin{array}{c}0.001 \\
(0.002)\end{array}$ & $\begin{array}{l}-0.001 \\
(0.001)\end{array}$ & $\begin{array}{l}-0.001 \\
(0.002)\end{array}$ \\
\hline$T S_{i t} \times \rho_{i, t}$ & $\begin{array}{c}0.182 \\
(0.173)\end{array}$ & $\begin{array}{l}-0.154 \\
(0.247)\end{array}$ & $\begin{array}{c}0.275 \\
(0.125)^{*}\end{array}$ & $\begin{array}{c}0.520 \\
(0.112)^{* *}\end{array}$ \\
\hline$I S_{i t} \times \rho_{i, t}$ & $\begin{array}{l}-0.008 \\
(0.046)\end{array}$ & $\begin{array}{l}-0.028 \\
(0.629)\end{array}$ & $\begin{array}{l}-0.031 \\
(0.029)\end{array}$ & $\begin{array}{l}-0.033 \\
(0.032)\end{array}$ \\
\hline$B S_{i, t} \times \rho_{i, t}$ & $\begin{array}{l}-0.016 \\
(0.032)\end{array}$ & $\begin{array}{l}-0.030 \\
(0.040)\end{array}$ & $\begin{array}{c}0.043 \\
(0.045)\end{array}$ & $\begin{array}{c}0.052 \\
(0.163)\end{array}$ \\
\hline$\Delta y$ per capita citt & $\begin{array}{c}-0.154 \\
(0.083)^{+} \\
\end{array}$ & $\begin{array}{c}-0.237 \\
(0.127)^{+} \\
\end{array}$ & $\begin{array}{c}0.162 \\
(0.138)\end{array}$ & $\begin{array}{c}0.312 \\
(0.115)^{* *} \\
\end{array}$ \\
\hline Panel Observations & 1,794 & 623 & 1,171 & 680 \\
\hline$R$-squared & 0.301 & 0.276 & 0.427 & 0.668 \\
\hline
\end{tabular}

(Notes) (i) The country dummies and quarter dummies are included in all regressions but not reported.

(ii) Standard errors are given in parentheses.

(iii) + denote statistically significant at the $10 \%$ level, * denote statistically significant at the $5 \%$ level, ** denote statistically significant at the $1 \%$ level.

(iv) 'After Zone' stands for the after Euro zone membership.

In and of itself, economic coordination is not found to have any major impact on crisis likelihood for any of the groups, with no changes detected over time. The only instance in which a contribution to the impact of sector connectivity on CCI is found is in trade connectivity: stronger trade connectivity between Eurozone countries based on economic coordination is seen to increase the risk of crisis, with an especially pronounced effect after Eurozone membership.

Finally, Table 12 below presents the estimated results of how fiscal vulnerability affects the relationship between connectivity and CCI by using Equation (14). 
Table 12. Channels influence on Currency Crisis Index

by bilateral fiscal vulnerability

\begin{tabular}{|c|c|c|c|c|}
\hline Dependent variable & \multicolumn{4}{|c|}{$C C I_{i t}$} \\
\hline Sample & EU 27 & Non euro 10 & Euro 17 & $\begin{array}{c}\text { Euro 17 } \\
\text { (After Zone) }\end{array}$ \\
\hline$F V_{i, t}$ & $\begin{array}{l}-0.063 \\
(0.467)\end{array}$ & $\begin{array}{c}0.007 \\
(0.952)\end{array}$ & $\begin{array}{c}0.873 \\
(0.590)+\end{array}$ & $\begin{array}{c}2.895 \\
(0.552)^{* *}\end{array}$ \\
\hline Time varying $\times F V_{i, t}$ & $\begin{array}{c}0.001 \\
(0.001)\end{array}$ & $\begin{array}{c}0.003 \\
(0.003)\end{array}$ & $\begin{array}{l}-0.001 \\
(0.001)\end{array}$ & $\begin{array}{c}-0.007 \\
(0.002)^{* * *}\end{array}$ \\
\hline$T S_{i, t} \times F V_{i, t}$ & $\begin{array}{c}0.251 \\
(0.218)\end{array}$ & $\begin{array}{c}0.445 \\
(0.380)\end{array}$ & $\begin{array}{c}0.402 \\
(0.165)^{* *}\end{array}$ & $\begin{array}{c}1.054 \\
(0.163)^{* *}\end{array}$ \\
\hline$I S_{i, t} \times F V_{i, t}$ & $\begin{array}{l}-0.114 \\
(0.593)\end{array}$ & $\begin{array}{l}-0.423 \\
(1.200)\end{array}$ & $\begin{array}{c}-1.192 \\
(0.720)+\end{array}$ & $\begin{array}{c}-3.007 \\
(0.643)^{* *}\end{array}$ \\
\hline$B S_{i, t} \times F V_{i, t}$ & $\begin{array}{c}0.001 \\
(0.031)\end{array}$ & $\begin{array}{l}-0.020 \\
(0.065)\end{array}$ & $\begin{array}{l}-0.001 \\
(0.034)\end{array}$ & $\begin{array}{l}-0.104 \\
(0.099)\end{array}$ \\
\hline$\Delta y$ per capita $_{i, t}$ & $\begin{array}{c}-0.182 \\
(0.089)^{* *}\end{array}$ & $\begin{array}{c}-0.279 \\
(0.139)^{*}\end{array}$ & $\begin{array}{c}0.150 \\
(0.140) \\
\end{array}$ & $\begin{array}{c}0.309 \\
(0.111)^{* *} \\
\end{array}$ \\
\hline Panel Observations & 1,680 & 598 & 1,082 & 680 \\
\hline$R$-squared & 0.299 & 0.283 & 0.388 & 0.503 \\
\hline
\end{tabular}

(Notes) (i) The country dummies and quarter dummies are included in all regression but not reported.

(ii) Standard errors are given in parentheses.

(iii) + denote statistically significant at the $10 \%$ level, * denote statistically significant at the $5 \%$ level,

** denote statistically significant at the $1 \%$ level.

(iv) 'After Zone' stands for the after Euro zone membership.

Relative fiscal vulnerability between countries is found to have a larger effect on the relationship between sector connectivity and CCI than economic coordination. This is particularly true in the case of countries using the euro. To begin with, fiscal vulnerability itself increases the likelihood of a currency crisis in Eurozone countries, with an even stronger effect after membership. The increased risk occurs as vulnerability leads to stronger trade connectivity; conversely, stronger industry connectivity is associated with a lower risk of crisis (no statistically significant relationship was found with banking connectivity). This phenomenon was observed to operate even more strongly after membership in the Eurozone. 


\section{Concluding Remarks}

This paper estimates the degree of connectivity between the 27 countries of the European Union, which already has a longstanding history as a tightly bound economic community, and within it the 17 countries of the Eurozone, which are believed to have stronger sector-level connectivity than other countries, with a particular focus on the connection between those relationships and crisis indicators. In particular, it focuses on the main variables that influence connectivity between countries, determining the impact on the Currency Crisis Indicator (CCI), and the channels through which it travels, as structural changes in the economy and government finances interact with trade, industry, and banking connectivity between nations.

To achieve this, the paper has collected time series data from 1990 to 2011, and in order to express the estimation of the effect of these variables in greater detail, it has assembled not annual data but quarterly data. This adds up to a total of 88 quarters of data for each country from the first quarter of 1990 to the fourth quarter of 2011.

This paper is able to use the results of empirical analysis to draw the following three conclusions.

First, economic fluctuations, fiscal deficit conditions, and degree of economic interaction are all found to have a powerful effect on connectivity between Eurozone nations, especially in the areas of trade and banking. Countries that use the euro are found to engage in more economic cooperation than non-euro countries after joining the zone, but that coordination does not increase their trade connectivity, a fact that appears to stem from the differing influences on trade connectivity during times of relative economic prosperity and decline. Trade connectivity also weakens with greater government deficit conditions and relative fiscal vulnerability, suggesting an effect from deepening trade imbalance that may result from disparities in fiscal strength. A deepening fiscal deficit is associated with increased banking connectivity between countries, while differences in fiscal strength - that is, increasing relative fiscal vulnerability - are found to weaken banking connectivity. This trend is especially pronounced after membership in the Eurozone.

Second, the CCI for countries that have adopted the euro is also observed to increase continuously after Eurozone membership. Trade and banking connectivity are found to lower the risk of crisis for the 17 countries that use the currency, as opposed to the 10 that do not, but trade connectivity is actually associated with a substantial increase in 
CCI. The increased likelihood of crisis associated with this connectivity in Eurozone nations, despite the higher levels of trade connectivity after membership, is attributed to trade deficits within the region. Unlike their counterparts with different currencies, countries that use the euro experienced a heightened risk for currency crisis due to trade deficits that resulted from trade with partner countries, a trend that is especially salient after zone membership.

Third, economic coordination is observed to have a more negative effect on currency crisis risk for Eurozone countries than relatively fiscal vulnerability. However, vulnerability accounts for a larger portion of the impact of trade connectivity on crisis likelihood than does coordination. While the stronger trade connectivity that results from coordination is seen to increase the likelihood of a currency crisis in Eurozone countries, stronger trade connectivity within the euro community has a greater negative impact on the risk of a currency crisis than economic coordination when one country is relatively weaker than another in its fiscal conditions. The risk is seen to be more than two times greater after Eurozone membership. This phenomenon can be traced to the relationship between fiscal and trade deficits; as the recent example of the Eurozone countries shows, increased fiscal deficits lead to increased trade deficits. The findings also show that an increase in the trade deficit leads to a higher risk of a currency crisis. It may be argued that the reason that relative fiscal vulnerability strengthens the relationship between trade connectivity and crisis risk has to do with the growing trade imbalance between countries that results from an increasing fiscal deficit.

In conclusion, trade connectivity is found to be stronger after membership in the Eurozone, where cohesion is stronger than for the EU system as a whole, but growing conditions of trade imbalance resulting from trade deficit conditions meant that this connectivity increases the likelihood of a currency crisis. Also, while trade connectivity between Eurozone countries is stronger under conditions of economic coordination and relative fiscal vulnerability, this arguably adds to crisis risk, especially when the connectivity was the result of relative vulnerability. 


\section{References}

Baldacci, Emanuele, James McHugh, and Iva Petrova, "Measuring Fiscal Vulnerability and Fiscal Stress: A Proposed Set of Indicators," IMF Working Paper 11/94 (2011).

Barattieri, Alessandro, "Comparative Advantage, Service Trade, and Global Imbalances," Journal of International Economics 92(1) (2014): 1-13.

Barnes, S., J. Lawson, and A. Radziwill, "Current Account Imbalances in the Euro Area: A Comparative Perspective," OECD Economics Department Working papers 82 (2010).

Berger, Helge, and Volker Nitsch, "Bilateral Imbalance in Europe," CESifo Economic Studies 59(3) (2013): 559-575.

Brzozowski, Michal, Sadananda Prusty, "Impact of GDP Volatility on Current Account Balances," International Journal of Economics and Business Research 5(3) (2013): 239252.

Bulut, Levent, "External Debts and Current Account Adjustments," The B.E. Journal of Macroeconomics 11(1) (2009): 1-37.

Bussiere, Matthieu, Marcel Fratzscher, and Gernot J. Müller, "Productivity Shocks, Budget Deficits and the Current Account," Journal of International Money and Finance 29(8) (2010): 1562-1579.

Chinn, Menzie D., and Hiro Ito, "Current Account Balances, Financial Development, and Institutions," Journal of International Money and Finance 26(4) (2007): 546-569.

Corsetti, Giancarlo, and Gernot Müller, "Twin Deficits: Squaring Theory, Evidence and Common Sense," Economic Policy 21(48) (2006): 597-638.

Craighead, William D., and David R. Hineline, "As the Current Account Turns: Disaggregating the Effects of Current Account Reversals in Industrial Countries," The World Economy 36(12) (2013): 1516-1541.

De Gregorio, Jose, and Rodrigo O. Valdes, "Crisis Transmission: Evidence from the Debt, Tequila, and Asian Flu Crisis," The World Bank Economic Review 15(2) (2001): 289-314.

Demyanyk, Yuliya, Charlotte Ostergaard, and Bent E. Sorensen, "Risk sharing and 
portfolio allocation in EMU," European Economy - Economic Papers 334 (2008).

Edwards, Sebastian, "How Effective Are Capital Controls?," Journal of Economic Perspective 14(4) (1999): 65-84.

Eichengreen, Bary, Andrew K. Rose, and Charles Wyplosz, "Contagious Currency Crisis," University of California, Berkeley July (1997).

Estrella, Arturo, and Frederic S. Mishkin, "Predicting U.S. Recessions: Financial Variables as Leading Indicators," The Review of Economics and Statistics 80(1) (1998): 45-61.

Fracasso, Andrea, and Stefano Schiavo, "Global imbalances, exchange rates adjustment and the crisis: Implications from network analysis," Journal of Policy Modeling 31(5) (2009): 601-619.

Frankel, Jeffrey A., and Andrew K. Rose, "Currency Crashs in Emerging Markets: An Empirical Treatment," Journal of International Economics 41 (1996) 351-366.

Fratzscher, Marcel, "On Currency Crisis and Contagion,” ECB Working paper 139 (2002).

Glick, Reuven, and Andrew Rose, "Contagion and Trade: Why are Currency Crisis Regional?," Journal of International Money and Finance 18(4) (1999): 603-618.

Poirson, Helene, and Sebastian Weber, "Growth Spillover Dynamics from Crisis to Recovery," IMF Working Paper 11/94 (2011).

Imbs, Jean, "Trade, Finance, Specialization and Synchronization," The Review of Economics and Statistics 86(3) (2004): 723-734.

Imbs, Jean, "The Real Effects of Financial Integration," Journal of International Economics 68(2) (2007): 296-324.

Jaumotte, Florence, and Piyaporn Sodsriwiboon, "Current Account Imbalance in the Southern Euro Area," IMF Working paper 139 (2010).

Kaminsky, Graciela, Saul Lizondo, and Carmen M. Reinhart, "Leading Indicators of Currency Crisis," IMF Working paper 79 (1997).

Karmann, Alexander, Oliver Greßmann, and Christian Hott, "Contagion of Currency Crises: Some Theoretical and Empirical Analysis," Deutsche Bank Research notes 02-2 
(2002).

Kim, Jong-Hee, Ki-Young Park, and Taeyoon Sung, "Does Fiscal Policy Help Those Who Need It Most? Evidence from the US and the Eurozone," Global Economic Review 41(1) (2012): 33-54.

Kotsios, Panagiotis, "Exploring the Effect of Trade Balance and Industrial Productions on National Debt," Journal of Applied Economic Sciences 7(1) (2012): 64-72.

Lane, Philip R., and Barbara Pels, "Current Account Imbalances in Europe," CEPR Discussion paper 8958 (2012).

Lee Young and Taeyoon Sung, "Fiscal Policy, Business Cycles and Economic Stabilisation: Evidence from Industrialised and Developing Countries," Fiscal Studies 28(4) (2007): 437-462.

Müller, Gernot, "Understanding the Dynamic Effects of Government Spending on Foreign Trade," Journal of International Money and Finance 27(3) (2008): 345-371.

Nickel, Christine, and Isabel Vansteenkiste, "Fiscal Policies, the Current Account and Ricardian Equivalence, “ECB Working paper series 935 (2008).

Sachs, Jeffrey, Aaron Tornell, and Andres Velasco, "Financial Crisis in Emerging Markets: The Lessons from 1995," Brookings Papers on Economic Activity 1 (1996).

Sorensen, B. and O. Yosha, "Is State Fiscal Policy Asymmetric over the Business Cycle?," Federal Reserve Bank of Kansas City Economic Review 3Q (2002): 43-64

Soukiazis, Elias, Pedro André Cerqueira, and Micaela Antunes, "Growth rates constrained by internal and external imbalances and the role of relative prices: Empirical evidence from Portugal,"Journal of Post Keynesian Economics 22(3) (2012): 259-282.

Truman, Edwin M., "Budget and External Deficits: Not Twins but the Same Family," paper presented at the Federal Reserve Bank of Boston Annual Research Conference June 14-16 (2004).

Van den End, Jan Willem, "Indicator and boundaries of financial stability", DNB Working paper 97 (2006). 